УДК 902/01

https://doi.org/10.24852/2587-6112.2021.3.24.42

\title{
БАЛЫМЕРСКОЕ СЕЛИЩЕ V: ИТОГИ ИССЛЕДОВАНИЙ 2019 Г.
}

\author{
(C) 2021 г. Р.Р. Валиев, Р.А. Степанов
}

Публикация посвящена итогам археологических исследований Балымерского V селища в 2019 г. Проведение работ обусловлено разрушением культурного слоя памятника разветвленной овражной сетью левого берега р. Волга. Впервые на Балымерском V селище в 1955 г. археологические раскопки под руководством А.М. Ефимовой провела Куйбышевская археологическая экспедиция. Двумя раскопами А.М. Ефимова выявила очаги, хозяйственные, жилые и «жертвенные» ямы, и установила существование поселения в именьковское и булгарское домонгольское время. По ее мнению, болгарское поселение прекращает свое существование к концу XI - началу XII вв. Исследования 2019 г. позволили уточнить датировку памятника. Исходя из результатов исследований, территория Балымерского V селища начала осваиваться в именьковское время (IV-VII вв.). В период Волжской Булгарии территория именьковского селища перерабатывается в результате хозяйственной деятельности и распашки. Время бытования булгарского поселения в результате исследований определено интервалом XI (скорее всего, его второй половины) - середины XIII вв. После монгольского завоевания, поселение продолжало существовать на этапе становления Улуса Джучи, о чём могут свидетельствовать находки монет 40-х гг. XIII в., обнаруженных как в культурном слое, так и в одном из объектов.

Ключевые слова: археология, Среднее Поволжье, Балымерское V селище, средневековье, именьковская культура, булгарское домонгольское время, раннезолотоордынский период, стратиграфия, находки, монеты.

\section{BALYMERY V SETTLEMENT: STUDY RESULTS OF 2019}

\section{R.R. Valiev, R.A. Stepanov}

The publication deals with the results of archaeological studies at Balymery V settlement in 2019. The work was carried out in relation to the destruction of the site's cultural layer by the branched ravine network of the left bank of the Volga river. The first archaeological excavations at Balymery V settlement were carried out in 1955 under the supervision of A.M. Efimova by the Kuibyshev archaeological expedition. Two excavations by A.M. Efimova allowed to identify hearths, economic, residential and "sacrificial" pits, and establish the existence of the settlement in the Imenkovo and Bolgar Pre-Mongol periods. In her opinion, settlement of the Volga Bolgars ceases to exist by the end of the $11^{\text {th }}$ - early $12^{\text {th }}$ centuries. The studies of 2019 made it possible to clarify the dating of the site. Based on study results, the development of the territory of Balymery V settlement began in the Imenkovo period $\left(4^{\text {th }}-7^{\text {th }} \mathrm{cc}\right.$.). In the Volga Bolgaria period, the territory of the Imenkovo settlement was developed as a result of economic activity and plowing. The existence period of the Volga Bolgars settlement was determined as the interval from the $11^{\text {th }}$ (most likely, its second half) - mid- $13^{\text {th }}$ centuries as a result of the studies. After the Mongol conquest, the settlement continued to exist in the Ulus of Jochi's formation period, as evidenced by the coins of the 1240s discovered both in the cultural layer and in one of the objects.

Keywords: archaeology, Middle Volga region, Balymery V settlement, Middle Ages, Imenkovo culture, Bolgar Pre-Mongol period, Early Golden Horde period, stratigraphy, finds, coins.

На территории Спасского района Республики Татарстан, расположенного в Западном Закамье, имеется не менее 340 объектов археологического наследия различных культур и исторических периодов. В окрестностях с. Балымеры локализуется более 10 памятников археологии (Археологическая карта Татарской АССР (Западное Закамье), 1986, c. 24-25; Свод археологических памятников Республики Татарстан, 2007, с. 320-321), а также обнаружено множество кладов вещей и монет (Археологическая карта..., 1986, c. 25-26). Практически все известные памятники Балымерской группы располагаются на краю третьей надпойменной террасы левобережья р. Волги (рис. 1).

Археологические памятники у с. Балымеры привлекали внимание исследователей с XIX в. (Шпилевский, 1877, с. 308). Главным образом, до наших дней раскопкам подвергались Балымерское городище «Шолом» (Спицын, 1916, с. 73-93; Смолин, 1926, с. 113-130; Жиромский, 1958, с. 424-450; Старостин, 1965, с. 59-68; Чижевский А.А. и др., 2017, с. 

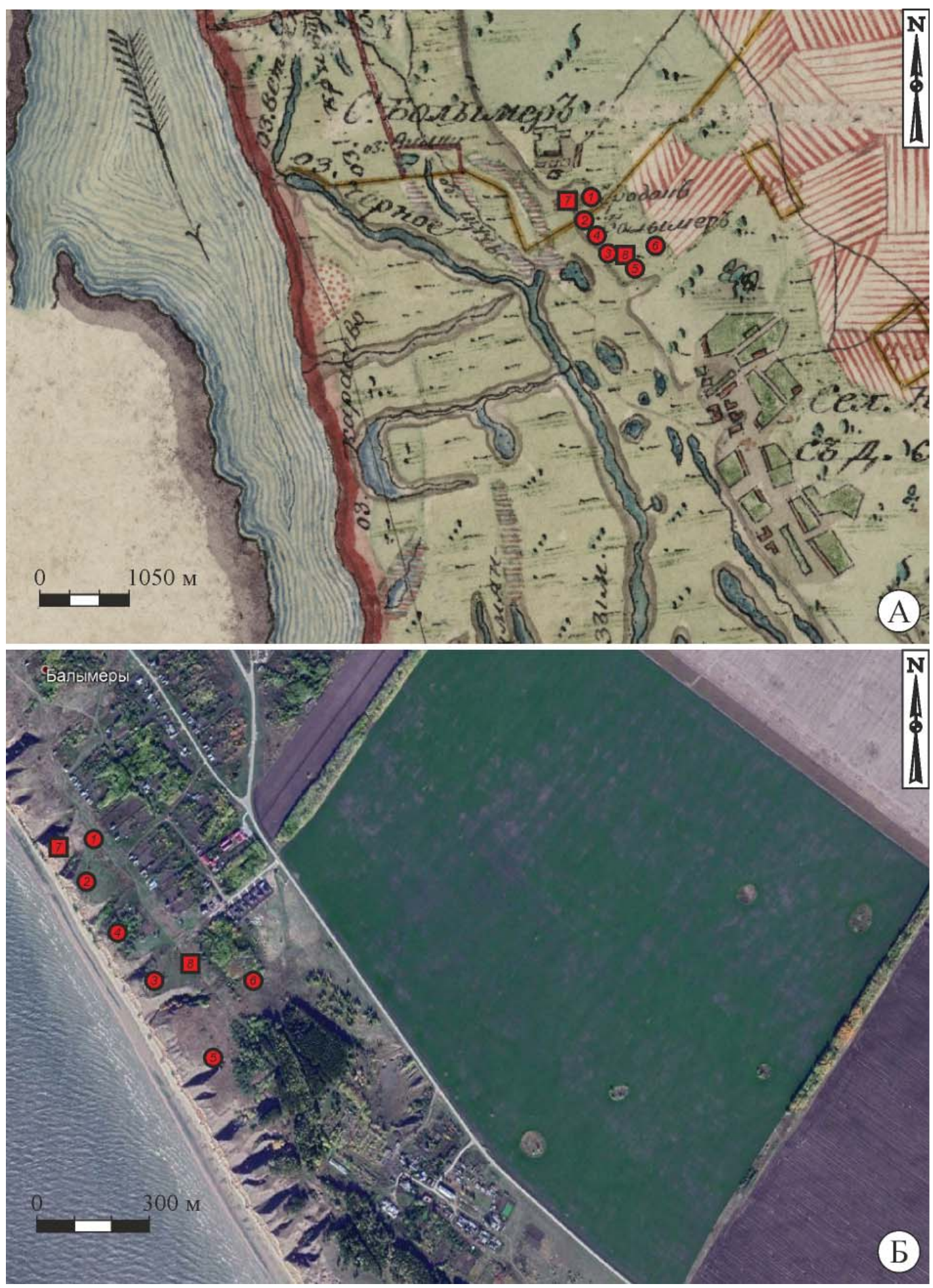

Рис. 1. Балымерская группа археологических памятников (1 - I селище, 2 - II селище, 3 - III селище, 4 - IV селище, 5 - V селище, 6 - VI селище, 7 - III городище «Шолом», 8 - I городище) на увеличенном фрагменте Генерального плана Спасского уезда конца XVIII в. (А) и на космоснимке (от 10.8.2018 г.) рассматриваемого района (Б)

Fig. 1. Balymery group of archaeological sites (1 - village I, 2 - village II, 3 - village III, 4 - village IV, 5 - village V, 6 - village VI, 7 - "Sholom" hillfort III, 8 - hillfort I) on an enlarged fragment of the General plan of Spassky District of the late $18^{\text {th }}$ century. (A) and in the satellite image (dated August 10, 2018) of the area (B)

108-126) и Балымерский курганный могильник (Смолин, 1926, с. 113-130; ОАК за 1893 г., 1985, с. 96-97; Халикова, 1965, с. 110-116).

Ряд археологических памятников на левобережье р. Волги был обнаружен разведочны- ми отрядами Государственного музея ТАССР, работавшими в составе экспедиции КФАН СССР в 1961 г. Наиболее многочисленными оказались памятники эпохи раннего Средневековья, в числе которых имеются Балы- 
мерское II городище «Турецкая крепость» именьковской культуры и, вероятно, новый Балымерский курганный могильник. Последний, по мнению Е.А. Халиковой, раскопавшей здесь четыре кургана, оставлен кочевниками, возможно, в период монгольского нашествия (Халикова, 1965, с. 110-116).

В 1963-1964 гг. при проведении раскопочных работ на Балымерском городище «Шолом» археологической экспедицией КФАН СССР под руководством П.Н. Старостина дополнительно обследовалась ближайшая округа. В результате работ им были выявлены пять селищ именьковской культуры (в том числе $\mathrm{V}$ селище), а также на плане обозначен грунтовый II могильник (Старостин, 1965, с. 60,63 , рис. 1$)$.

В 1996-1998 гг. Балымерская группа памятников была осмотрена К.А. Руденко, который составил новый общий топографический план памятников, а также провел охранные работы на II могильнике и выделенном им VI селище. На Балымерском II могильнике им исследовано 9 мусульманских погребений, которые он датировал XII-XIII вв. (Руденко, 2002, с. $72-73$, рис. $1-2$; 2004, с. 57 , рис. 13), на булгарском Балымерском VI селище, частично разрушенном карьером, обнаружены объекты и находки, датируемые XI-XII вв. (Руденко, 2004, с. 57, рис. 11-12).

Непосредственно на Балымерском V селище Куйбышевская археологическая экспедиция в 1955 г. впервые провела археологические раскопки под руководством A.M. Ефимовой. Площадку селища она ошибочно отождествляла с территорией Балымерского I городища. А.М. Ефимовой были заложены два раскопа общей площадью 286 кв. м, очертания которых заметны и ныне (рис. 2). Раскоп I был заложен на краю обрыва оврага в юго-восточной части, раскоп II - у обрыва оврага в центральной части памятника. Выявлены и исследованы именьковские углубленное четырехугольное жилище, два очага, «жертвенная яма» и ямы хозяйственного назначения, а также «остатки землянки, кострища, погреба и разного рода ямы» домонгольского болгарского периода. Собрана богатая коллекция находок, представленных фрагментами посуды, пряслицами, железными сошником, ножами, рыболовными крючками, замками, изделиями из цветного металла, костяными предметами и т. д. По мнению А.М. Ефимовой, болгарское поселение прекращает свое существование к концу XI - началу ХІІ вв. (Ефимова, 1962, с. 25-48).
Балымерское V селище расположено на краю третьей надпойменной террасы левого берега р. Волги в 0,95-1,27 км к юго-востоку от центра с. Балымеры в Спасском районе Республики Татарстан. Памятник занимает площадь размером $320 \times 350$ м и с юго-востока примыкает к Балымерскому I городищу (рис. 2). Площадка селища относительно ровная, плавно понижается на юго-запад к краю террасы. Поверхность памятника изрезана глубокими лесопосадочными бороздами, вытянутыми вдоль абриса берега. Северовосточная часть селища занята лесопосадкой, остальная территория задернована.

После образования Куйбышевского водохранилища в 1955-1957 гг. и затопления поймы склоны террасы подверглись интенсивным эрозионным процессам, что приводит к осыпанию культурного слоя в разветвленную овражную сеть левого берега р. Волги. Глубокие овраги ограничивают территорию селища с северо-запада и юго-востока, а также прорезают по центру. На наиболее разрушаемом участке в восточной части памятника в 2019 г. проведены исследования раскопом III площадью более 170 кв. м. Раскоп вытянут вдоль обрыва правого берега оврага по оси север - северо-запад - юг - юго-восток (азимут $173^{\circ}$ ). Поверхность раскопа задернована, плавно понижается от центра к северу и югу с перепадами высот от -9 до -34 см от 0. На южных участках раскопа имеется небольшая ложбинка с понижением до отметки -50 см от 0. С востока и юга площадка раскопа обрывается оврагом.

Мощность культурного слоя на раскопе III составила 40-86 см (рис. 3). Он покрыт дерном толщиной 3-6 см. Под дерном залегает культурный слой памятника, верхние отложения которого представлены бурой гумусированной супесью, мощностью до 16 см. Данный слой содержит керамику периода Волжской Булгарии, представленную I, XVII, XIII и XIV (с преобладанием первой) этнокультурными группами, выделенными Т.А. Хлебниковой (Хлебникова, 1984; 1988), переотложенную керамику именьковской культуры, а также кости животных. На основании стратиграфических наблюдений очевидно, что прослойка сформировалась в результате запустения поселения и использования его территории под пастбище в XIX - первой половине XX вв.

Ниже залегает слой булгарского поселения, просуществовавшего с XI в. (скорее всего со второй половины) до середины XIII в. Общая мощность слоя составляет 18-67 см. Он 


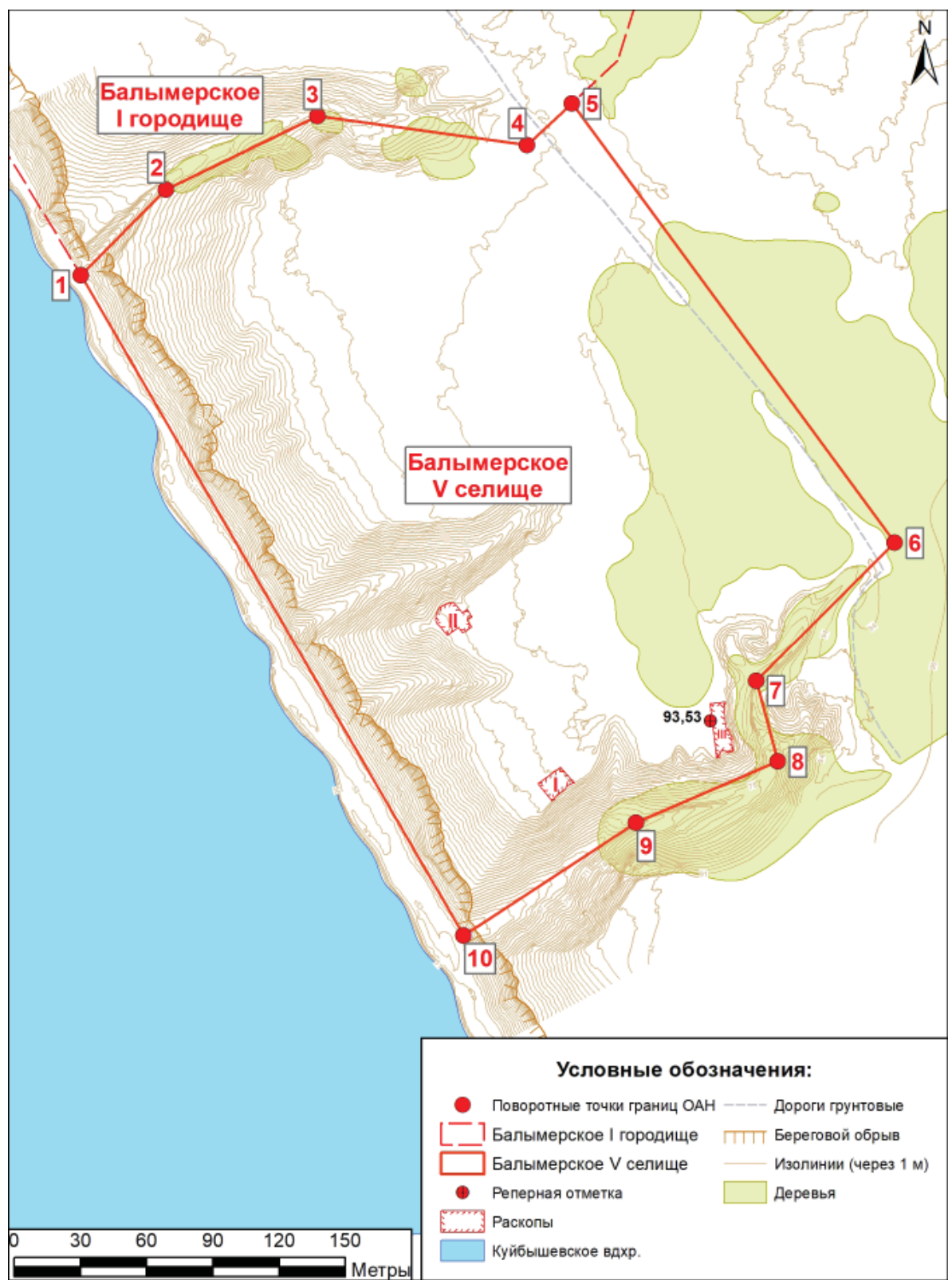

Рис. 2. Инструментальный топоплан Балымерского V селища с указанием раскопов

Fig. 2. Instrumental topographic plan of Balymery $\mathrm{V}$ settlement with an indication of the excavations

состоит из двух горизонтов: верхнего, образовавшегося в период завоевания монголами территории Волжской Булгарии и последующее время (до середины XIII в.); и нижнего слоя, сформировавшегося во время существования селища в домонгольский период (с XI по первую треть XIII в.).

Верхний горизонт мощностью 12-35 см включает несколько прослоек (сверху вниз): бурая супесь, темно-серая супесь, темносерая супесь с включениями суглинка, углей и темно-серая супесь с единичными включениями прокала. На зачистке на уровне пласта 3 на южных квадратах раскопа прослойка темно-серой супеси фиксировалась виде полос шириной 8-28 см и длиной 40-115 cм, вытянутых по оси ЗСЗ - ВЮВ. Данные поло- сы являются следами от борозд, образованных в результате распашки данного участка, по всей видимости, проведенной во второй четверти XIII в.

Среди находок верхнего горизонта, в основном представленных большим количеством костей животных, булгарской керамикой I группы и фрагментами переотложенной именьковской посуды (в том числе ошлакованной), наблюдается значительное число фрагментов посуды XVII группы, превышающее количество керамики иных типов. Прочий предметный ряд характеризуется медной монетой 40-х гг. XIII в., железными ножами, ошлакованными стеклянными бусами, глиняными пряслицами, изделиями из стенок керамических сосудов. 

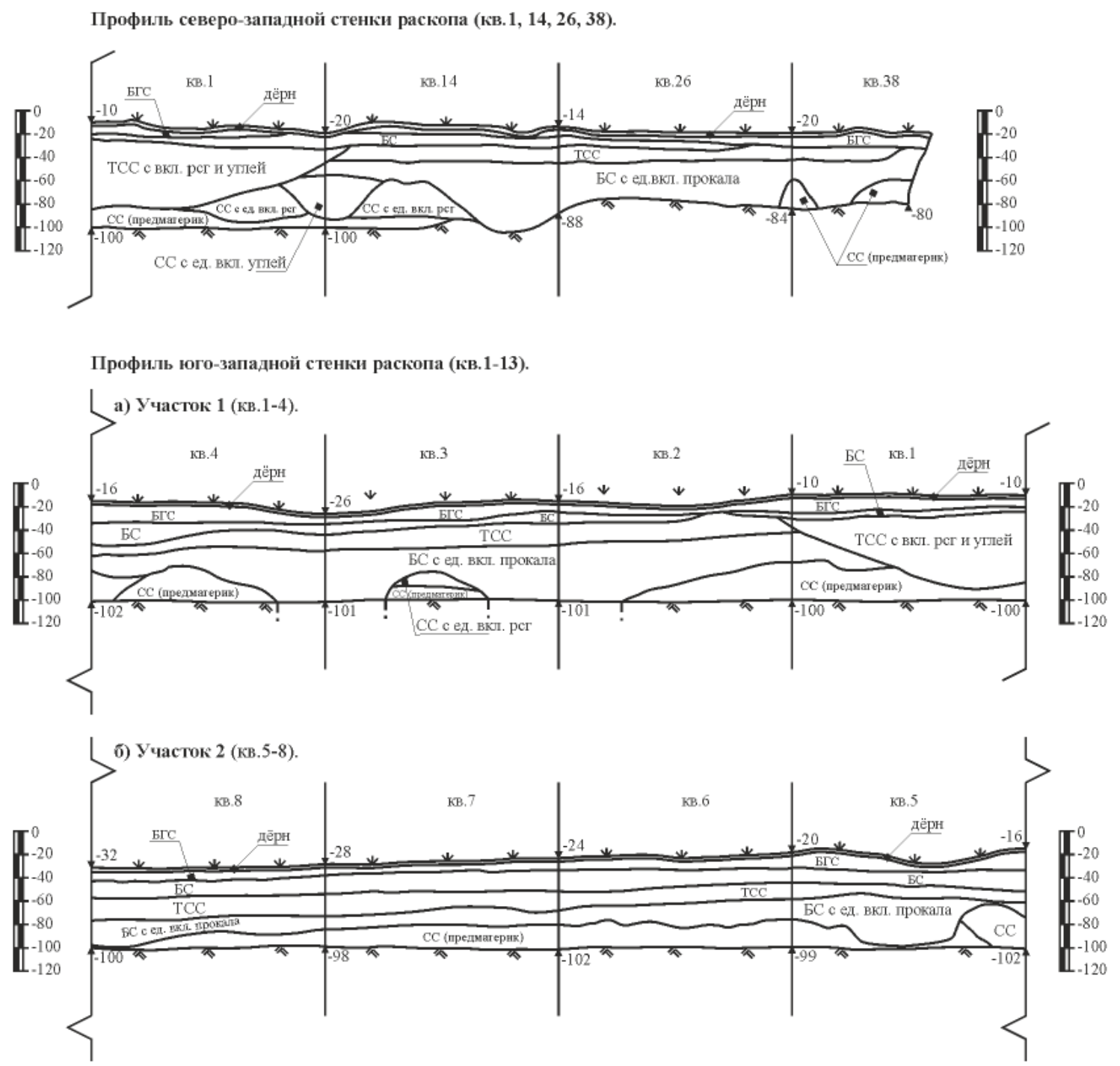

в) Участок 3 (кв.9-13).

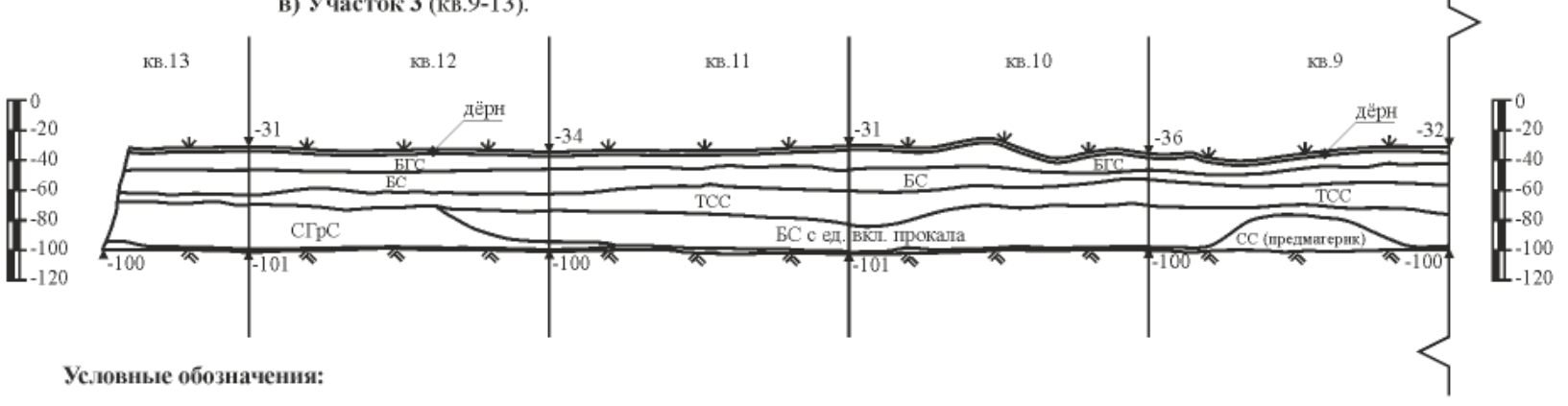

СC - серая супесь

ТСС - тёмно-серая супесь

СГрС - серая гранулированная супесь

БС - бурая супесь

БГС - бурая гумусированная супесь

pсr - рыжий суглинок

Нижний горизонт мощностью 5-50 см состоит из супеси бурого и серого цвета с различными вариациями включений прокала, углей и суглинка. Керамический комплекс нижнего горизонта аналогичен верхнему, однако в нем в два раза меньше фрагментов XVII группы, а именьковской керамики в 2 раза больше, чем булгарской керамики I группы. Среди индивидуальных находок появ- ляются железные уздечные или ременные накладки, топор и крючок от колчана.

Ниже располагается слой именьковского поселения, датируемый в целом хронологическими рамками данной культуры (IV-VII вв.). Общая мощность слоя, не переработанного в период существования булгарского поселения, достигает 32 см. Его характеризует серая гранулированная супесь и несколь- 
ко прослоек, концентрирующихся на месте расположения ям 8 и 9: светло-серая гумусированная супесь с включениями песка и золы, светло-серая супесь с включениями суглинка, серая супесь с включениями углей. Находки представлены лепной керамикой указанного времени, биконическим керамическим пряслицем и фрагментом железного ножа.

Культурный слой покоится на погребенной почве (серая супесь), толщиной до 30 см. Верхние ее горизонты частично переработаны в период существования именьковского и булгарского поселений. Материк - бурый и рыжий суглинок.

На раскопе обнаружено 10 объектов (рис. 4). Из них яма 7 связана с верхним горизонтом булгарского селища (вторая четверть XIII в.), 6 объектов (ямы 1-5 и 10) датируются временем существования булгарского домонгольского селища (с XI по первую треть XIII в.), 3 объекта (ямы 6, 8, 9) относятся к именьковской культуре (IV-VII в.).

Яма 1 начала проявляться в виде просадки грунта (темно-серая супесь с единичными включениями прокала) и четко оконтурилась на следующем пласте 5 (-100 см от 0) на кв. 6, 19 в виде пятна овальной формы размером $198 \times 163$ см, вытянутого по оси ВСВ - ЗЮ3. Яма имеет асимметрично скошенные стенки, которые на глубине 67 см от верхнего края (-156 см от 0) переходят в отвесные. Вероятно, изначально стенки ямы были вертикальными, о чём свидетельствуют ровные края предматерика, просевшего большим блоком в заполнение ямы. Ровное плоское дно покоится на глубине -266 см от 0 (глубина ямы не менее 177 см). С верхней прослойки, являющейся просадкой грунта, происходят фрагменты круговой общеболгарской и лепной именьковской керамики, кости животных, а также керамическое биконическое пряслице. Пряслице коричневого цвета тщательно заглажено и имеет четко выраженное ребро. Диаметр 2,9 см, диаметр отверстия 1,5 см, высота 1,4 см. Данные пряслица типичны для именьковской культуры региона. Находки непосредственно из заполнения ямы представлены железным ножом, костями животных, фрагментами горшков, кувшинов и корчаги круговой общеболгарской посуды (I группа), единичными фрагментами горшков XVII группы и именьковской культуры. Яма 1 имела хозяйственное назначение и, по стратиграфическим наблюдениям, функционировала в XII в.

Яма 2 начала проявляться в виде просадки грунта (темно-серая супесь с единичными включениями прокала) и четко оконтурилась на следующем пласте 4 (-80 см от 0) на кв. 26 в виде пятна округлой формы диаметром 123 см. Яма имеет вертикальные сверху и расширяющиеся ко дну стенки, плавно переходящие в ровное плоское дно, которое покоится на глубине -220 см от 0 (глубина ямы не менее 143 см). Среди находок из заполнения ямы с явным преобладанием керамики I группы (57 фр., среди которых реконструируемый горшочек) попадаются экземпляры XVII группы (3 фр.), переотложенная лепная именьковская керамика (11 фр., в том числе 5 фр. ошлакованной), встречен 1 мелкий фрагмент круговой керамики с органикой в тесте. Остальной материал представлен костями животных, а также печиной, мелкими камнями, шлаком и т. д. Кроме того, из ямы происходит фрагмент каменной литейной формы. Яма 2 хозяйственного назначения функционировала, вероятно, в XII - первой трети XIII вв.

Яма 3 выявлена на уровне пласта 5 (-100 см от 0) на кв. 5 в виде пятна округлой формы диаметром 176 см. Ко дну она расширилась до размеров $230 \times 196$ см на кв. 4-5, 18. Вертикальные сверху стенки ямы расширяются ко дну. Вероятно, изначально стенки ямы имели грушевидную или колоколовидную в разрезе форму, на что косвенно могут указывать блоки предматерика и материкового суглинка, обвалившегося в заполнение ямы. Ровное плоское дно в восточной части имеет понижение на глубину 14 см, с отметки -274 до -286 см (глубина ямы не менее 196 см). Заполнение ямы состояло из прослоек, образовавшихся в результате засыпки, обвала стенок и функционирования ямы. Массовые находки: кости животных (352 шт.), керамика I группы (368 фр.), переотложенная именьковская (64фр., в том числе 30 фр. ошлакованной), лепная керамика с песком (1 фр.), печина, камни. При этом чрезвычайно большое количество костей животных (298 шт.) и керамики I группы (222 фр.), представленной разнообразной посудой (кувшины, кружки, горшки, корчаги, миски), происходит с прослойки, перекрывающей отложения периода функционирования. Это свидетельствует о вторичном использовании в качестве мусорной ямы объекта, первоначально исполнявшего хозяйственные функции (хранение и т. п.). Впоследствии, после обрушения стенок, яма была рекультивирована культурным слоем поселения, на что указывают находки из третьей прослойки заполнения объекта, содержащие в большом количестве общебулгарскую (133 фр., в том числе развал 


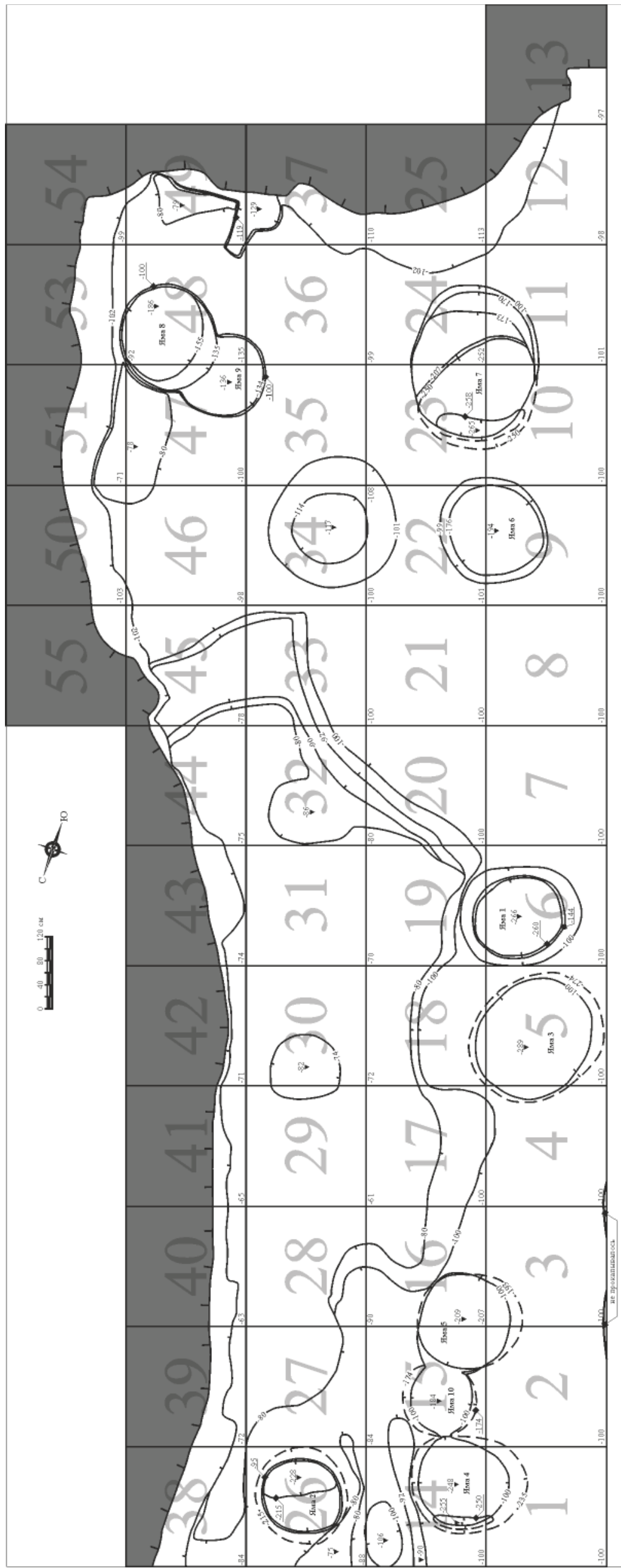

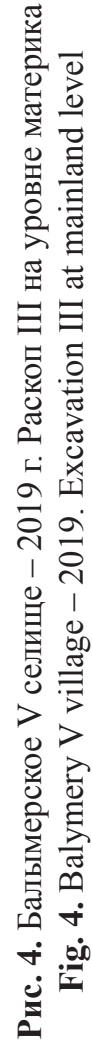


горшка) и именьковскую (56 фр.) керамику. Кроме того, из данной прослойки происходят фрагмент костяной накладки и два изделия из стенок керамических сосудов. Яма 3 первоначально имела хозяйственное назначение, после чего использовалась в качестве мусорной или помойной ямы. По стратиграфическим наблюдениям, период функционирования относится XII - первой трети XIII вв.

Яма 4 выявлена на уровне пласта 5 (-100 см от 0) на кв. 1, 14 в виде пятна округлой формы диаметром 128 см вместе со скоплениями объектов к югу от него. При выборке приобрела овальную форму размером $163 \times 152 \mathrm{~cm}$, вытянутую по оси ВСВ - ЗЮЗ. Яма имеет асимметрично расширяющиеся ко дну стенки, плавно переходящие в ровное плоское дно, которое покоится на глубине -245 см от 0 (глубина ямы не менее 145 см). Находки: фрагменты керамики I группы (240 фр., в том числе реконструируемые блюдо и корчага), XIII группы (3 фр.), XVII группы (11 фр.), переотложенная именьковская керамика (25 $\phi p)$, ошлакованная керамика (2 фр.), печина (29 шт.), камни (5 шт.) и кости животных (133 шт.). Яма 4 являлась хозяйственной ямой, вероятно, XII в., которая до засыпки непродолжительное время использовалась в качестве мусорной.

Яма 5 выявлена на уровне пласта 5 (-100 см от 0) на кв. 2-3, 15-16 в виде пятна округлой формы диаметром 142 см, соединяющейся со скоплениями объектов к северу от него. При выборке яма приобрела овальную форму $163 \times 152$ см, вытянутую по оси ВСВ - ЗЮ3. Стенки ямы вертикальные, западная стенка с подпоем, возможно, сформировавшимся в результате разрушения части стенки. Плоское дно покоится на глубине -208 см от 0 (глубина ямы не менее 108 см). Заполнение ямы состояло из прослоек, образовавшихся в результате просадки грунта, засыпки и обвала стенок ямы. Находки представлены керамикой I группы (87 фр.), XVII группы (1 фр.), переотложенными фрагментами именьковских горшков (17 фр., в том числе ошлакованная -3 фр.), печиной (2 шт.), камнями (3 шт.) и костями животных (64 шт.). Яма 5 имела хозяйственное назначение и функционировала, возможно, в XII в.

Яма 6 выявлена на уровне пласта 5 (-100 см от 0) на кв. 9, 22 в виде пятна круглой формы диаметром 132 см. Яма имеет чуть скошенные стенки и плоское ровное дно на глубине -193 см от 0 (глубина ямы не менее $93 \mathrm{~cm}$ ). В заполнении ямы светло-серая супесь с включения- ми суглинка мощностью до 43 см залегала на серой супеси с включениями суглинка мощностью 47-72 см. Немногие находки представлены костями животных (3 шт.), именьковской лепной керамикой (6 фр.), шлаком (1 шт.) и случайным фрагментом общеболгарской керамики. Яма 6 имела хозяйственное назначение и, по стратиграфическому положению и находкам, датируется периодом именьковской культуры (IV-VII вв.).

Яма 7 выявлена на уровне пласта 5 (-100 см от 0) кв. 10-11, 23-24 в виде пятна овальной формы размером $256 \times 202 \mathrm{~cm}$, вытянутого по оси С3 - ЮВ. Яма имеет вертикальную, расширяющуюся ко дну (с подбоем) северозападную стенку, остальные стенки вертикальные. У юго-восточной стенки расположены материковые ступеньки: на глубине $70 \mathrm{~cm}$ от верхнего края (-170 см от 0) шириной до 33 см и на глубине 107 см от верхнего края (-207 см от 0) шириной до 72 см. Дно ямы ступенчатой формы, понижается с юго-востока на северо-запад с отметки -250 см до -265 см (глубина ямы не менее 165 см). Возможно, подобная форма дна объекта объясняется наличием двух ям, прорезающих одна другую. Заполнение ямы состояло из прослоек, образовавшихся в результате просадки грунта, засыпки и обвалившихся стенок ямы. Из заполнения ямы происходят керамика I группы (73 фр., в том числе развалы двух горшков), XIII группы (1 фр.), XVII группы (1 фр.), переотложенная именьковская керамика (38 фр., в том числе 7 ошлакованных фр.), лепная керамика с подлощённой поверхностью (1 фр.), кости животных (60 шт.). На второй ступеньке расчищен костяк кошки. Кроме того, из заполнения ямы (с глубины -158 см и -194 см от 0) происходят 2 медные монеты - булгарские фельсы, чеканенные с именем покойного багдадского халифа ан-Насир ли-дин Аллаха. Обе монеты относятся к типу № 7 (вес 3,67 г), одна к варианту № 7а (вес 1,98 г) по типологии А.3. Сунгатуллиной и датируются 40-ми гг. XIII в. (Сунгатуллина, 2003, с. 15, 71-72). Согласно нумизматическим находкам, хозяйственная яма 7 датируется второй третью XIII в.

Яма 8 начала проявляться на уровне пласта 4 (-80 см от 0) в кв. 47-48, 53 в виде пятна овальной формы $208 \times 172$ см, вытянутого по оси 3 - В. На уровне следующего пласта 5 (-100 см от 0) в кв. 35-36, 47-48, 53 проявилась как пятно «восьмеркообразной» формы $263 \times 166$ см, вытянутое по оси ВЮВ - 3С3, образовавшееся в результате слияния двух округлых пятен от заполнения ям 8 и 9. В 
процессе выборки выяснилось, что яма 8 располагалась на кв. 47-48, 52-53 и в плане имела округлую форму диаметром 166 см. Она прорезает яму 9, имеет покатую западную и остальные вертикальные стенки. Дно понижается с запада на восток с отметки -160 см до -172 см (глубина ямы не менее 92 см). Заполнение ямы состояло из прослоек, образовавшихся в результате просадки грунта, обрушения стенок и сгоревшего перекрытия. Находки с верхней прослойки представлены фрагментами лепных горшков именьковской культуры (22 фр., в том числе 4 ошлакованных $\phi p$.$) , лепная керамика с подлощённой поверх-$ ностью (1 фр.), печина, шлак, кости животных (2 шт.), случайная керамика I группы (2 фр.). Основное заполнение содержало именьковскую керамику (20 фр., в том числе 1 ошлакованный фр.) и 2 случайных фрагмента общеболгарской керамики.

Яма 9 располагалась на кв. 35-36, 47-48, 53 , в плане имела округлую форму диаметром 144 см. Ее дневная поверхность располагалась между отметками -80/-100 см от 0. Яма имеет чуть скошенные стенки, плавно переходящие в ровное плоское дно с незначительным понижением к центру, и покоится на глубине -138 см от 0 (глубина ямы не менее $38 \mathrm{~cm}$ ). Заполнение однородное. Находок не обнаружено. Ямы 8 и 9 имели хозяйственное назначение и относятся к именьковской культуре, но по стратиграфическим наблюдениям яма 8 позднее ямы 9.

Яма 10 выявлена на уровне пласта 5 (-100 см от 0) на кв. 15 в виде пятна неопределённой формы, соединяющегося со скоплениями объектов к северу (яма 4) и югу (яма 5) от него. При выборке яма приобрела круглую форму диаметром $90 \mathrm{~cm}$, которая на уровне дна расширилась в диаметре до 124 см. Стенки ямы с подбоем, чашевидное в разрезе дно покоится на глубине -183 см от 0 (глубина ямы не менее 108 см). Находки: керамика І группы (9 фр.), именьковская (11 фр., в том числе 1 ошлакованный фр.), кости животных (10 шт.). Яма 10 является хозяйственной и функционировала, по стратиграфическим наблюдениям, в XI в.

В керамическом комплексе раскопа, насчитывающем 4173 обломка сосудов, в том числе реконструируемых, выделяется лепная, подправленная на подставке или круге, и круговая посуда. При определении керамики использовалась классификация Т.А. Хлебниковой, разработанная для памятников Волжской Булгарии (Хлебникова, 1984; 1988).
Круговая посуда с раскопа количеством 2123 фрагментов $(50,88 \%)$ составляет половину всего керамического материала, из них 12 фрагментов ошлакованных $(0,57 \%)$ и в основном состоит из I (общеболгарской) группы - 2104 фрагментов (99,7\% круговой посуды, или 50,42\% из общей массы керамики). Она окислительного обжига коричневого, красного и бурого цвета, выполнена из глиняной массы с малозаметными примесями мелкого песка, иногда встречаются запесоченные фрагменты, у 11 фрагментов имеются включения мелкодробленой органики. Ассортимент посуды разнообразен: горшки, корчаги, кувшины, кружки, миски, блюда, чашки, подавляющее большинство которых имеет лощение, в одном случае зафиксировано круговое лощение по внешнему краю дна. Традиционный орнамент I группы линейный, волна и гребенчатый штамп. Сосуды выполнены как в технике ленточного налепа, так и вытянуты из цельного куска глины (рис. 5: 1-9). На дне реконструируемого блюда I группы имеется рельефно-выпуклый знак-клеймо «ветка» (тип 53), который датируется VIII-XIV вв., но чаще встречается в слоях XI-XII вв. (Кокорина, 2002, с. 162, рис. 106) (рис. 5: 1).

Отдельную группу круговой керамики формируют фрагменты древнерусских горшков (XIV группа), в формовочной массе которых присутствуют примеси песка и дресвы, в одном случае дресвы и шамота. Поверхность шероховатая коричневого, темно-коричневого и белого цвета, украшены линейным орнаментом. Их обнаружено всего 7 фрагментов (0,3\% круговой керамики) (рис. 5: 10-11).

Выделанная от руки и подправленная на круге керамика представлена группами XIII и XVII. Первая характеризуется значительным содержанием кварцевого песка в формовочной массе и следами горизонтальной срезки лишней глины. Данная группа насчитывает 13 фрагментов $(0,31 \%$ от общего количества массового керамического материала). Она представлена обломками круглодонных горшков коричневого и красного цвета с характерным орнаментом в виде многорядной волны (рис. 5: 12-14).

XVII группа с мелкопесочным тестом и следами горизонтальной срезки лишней глины более представительна - 85 фрагментов $(2,04 \%$ от общей массы керамического материала). Это горшки с коричневым черепком, в редких случаях с характерным орнаментом в виде волны-змейки (рис. 5: 15-18). По мнению Т.А Хлебниковой, переходные от 

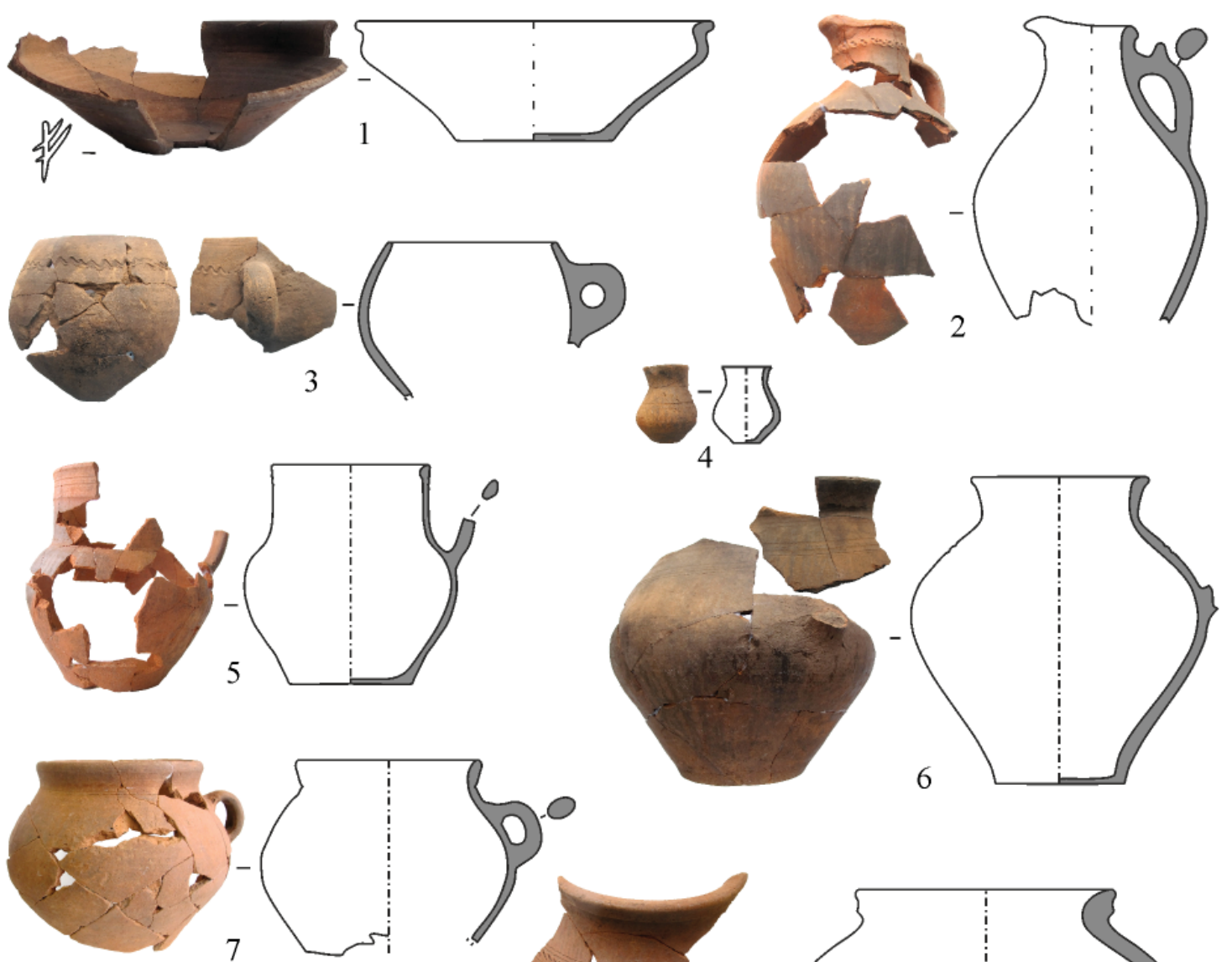

6
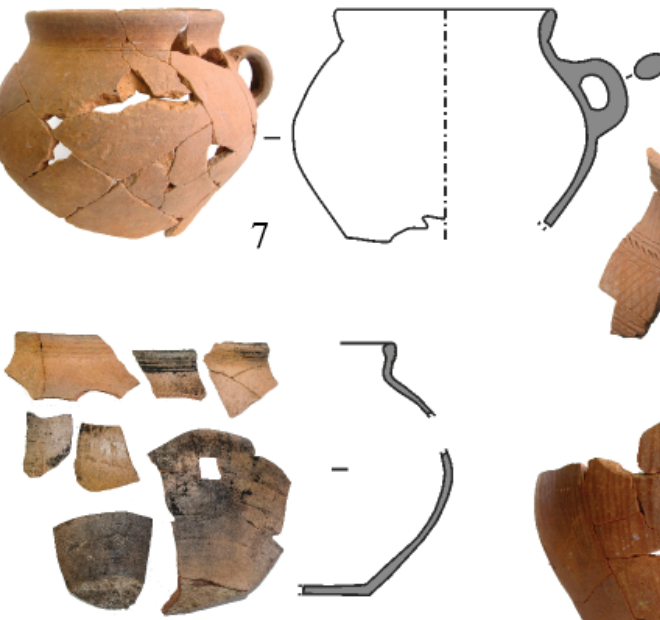

8
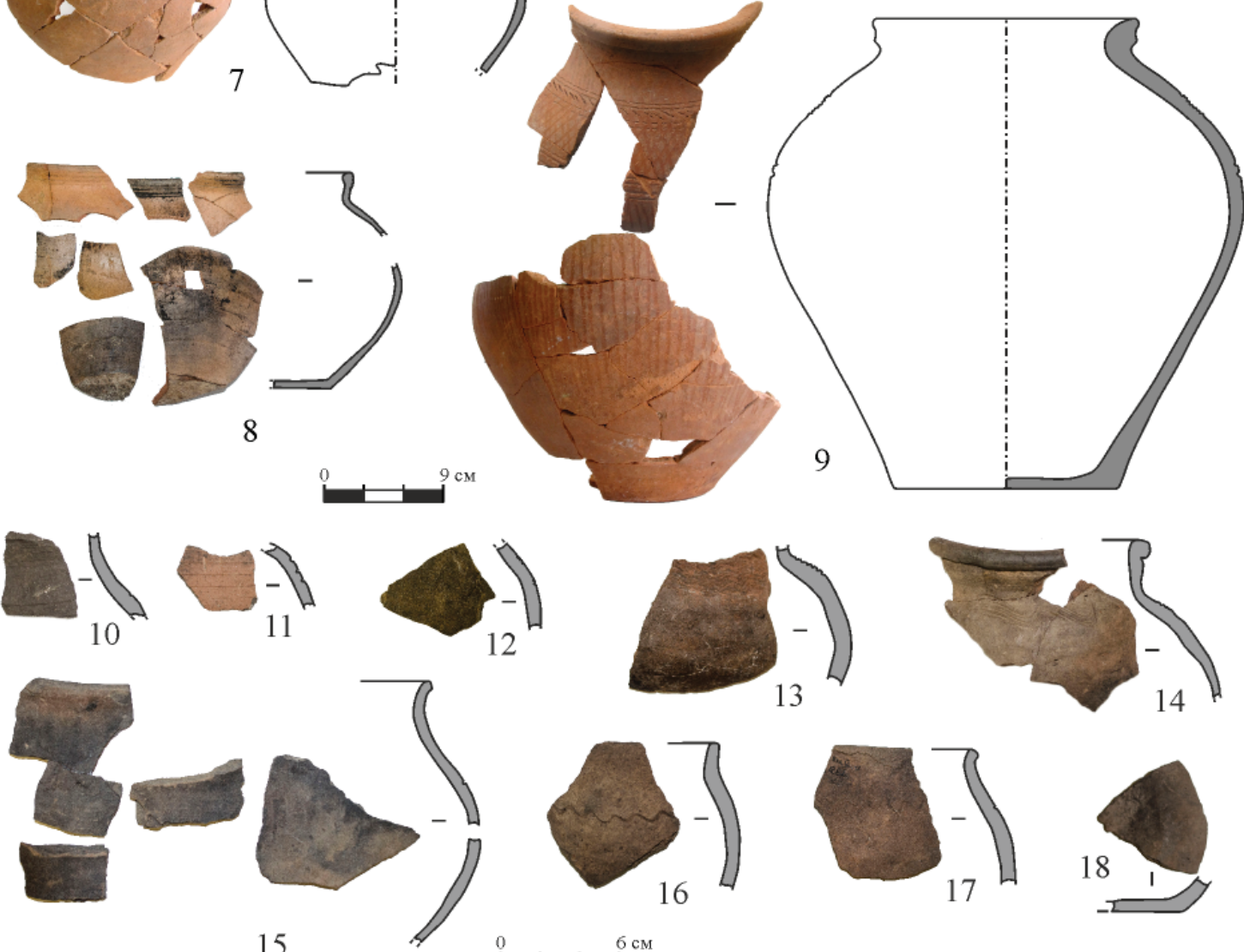

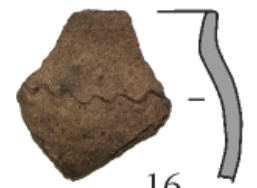

16

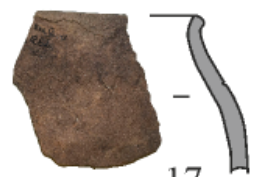

17

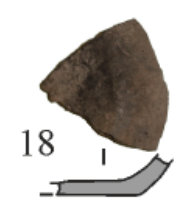

Рис. 5. Балымерское V селище - 2019 г. Вещевой комплекс раскопа III: круговая и подправленная керамика Fig. 5. Balymery V settlement - 2019. Item complex of excavation III: circular and mended ceramics

круглодонной к плоскодонной формы керамики данной группы датируются XI-XII вв. (Хлебникова, 1988, с. 27), Н.А. Кокорина появление этой группы относит к XII в. (Кокорина, 2002, c. 31).
Основная масса лепных сосудов - «классическая» керамика именьковской культуры бурого, коричневого и темно-коричневого цвета с примесями шамота различных размеров (чаще крупного) в формовочной массе 

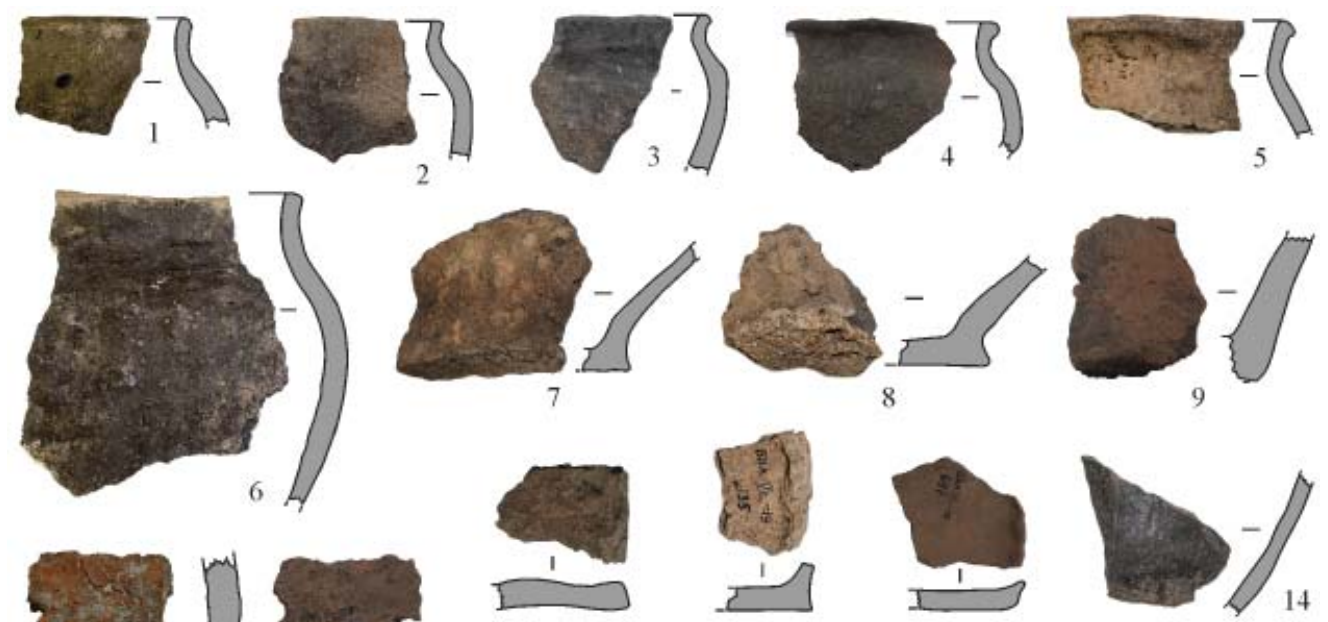

12
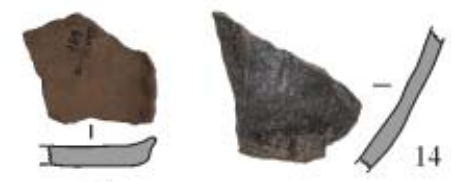

13

10
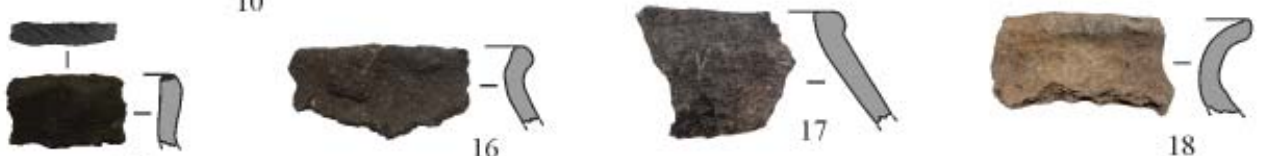

15
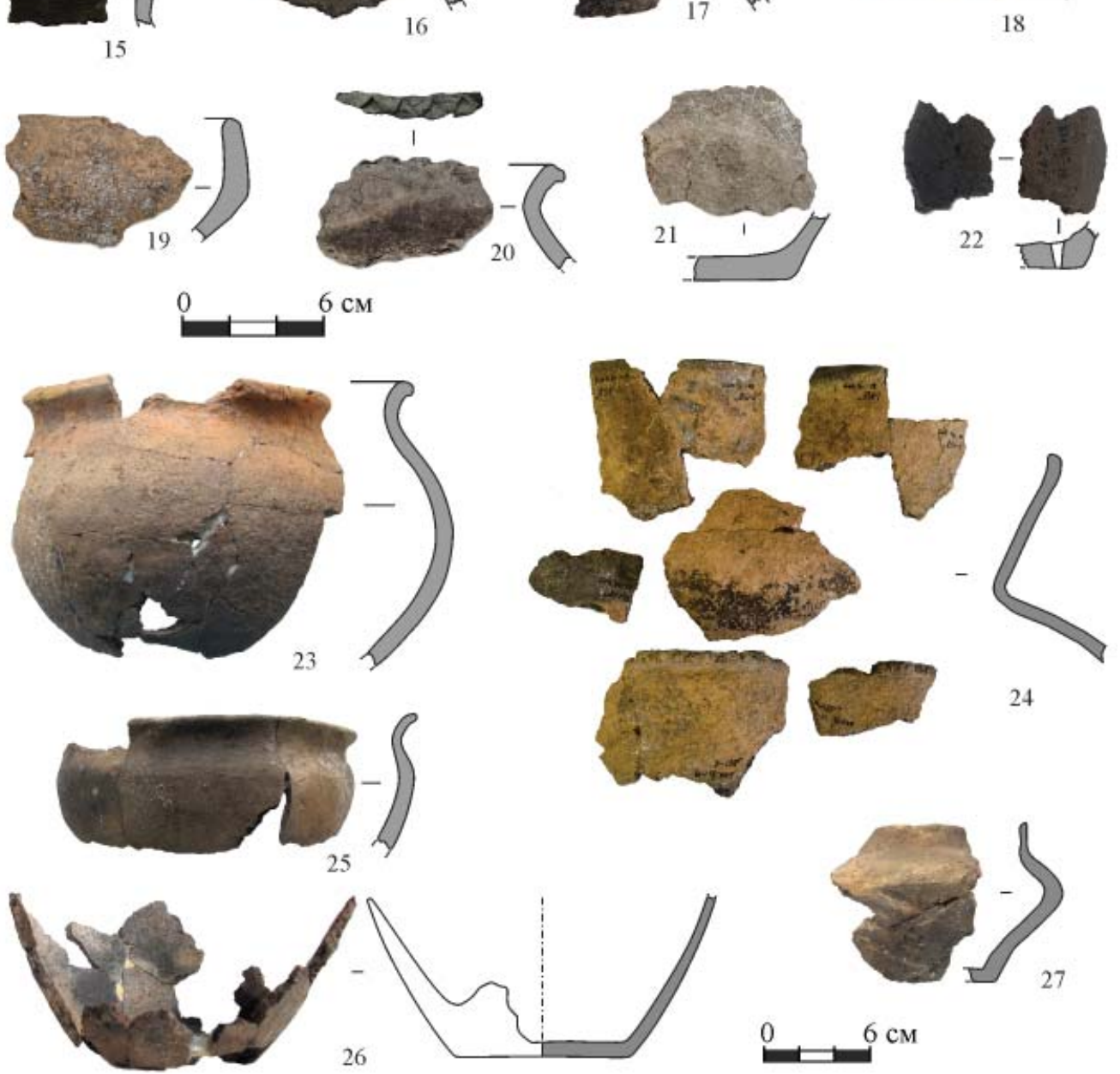

Рис. 6. Балымерское V селище - 2019 г. Вещевой комплекс раскопа III: лепная керамика раскопа III

Fig. 6. Balymery V settlement - 2019. Item complex of excavation III: molded ceramics from excavation III

(рис. 6: 1-13). Поверхность керамики бугристая, со следами заглаживания, вероятно, пучком травы. С раскопа их происходит 1888 фрагментов $(45,24 \%)$, среди которых довольно много ошлакованных - 609 фрагмент $(32,26 \%$ из числа именьковской керамики). Некоторые из них принадлежат жаровням или дискамсковородам без бортика или со слабо выраженным бортиком высотой не более $0,2-0,7 \mathrm{~cm}$ (рис. 6: 11-13). Подавляющее же большинство керамики относится к горшкам с невысоким прямым или отогнутым наружу венчиком. На 

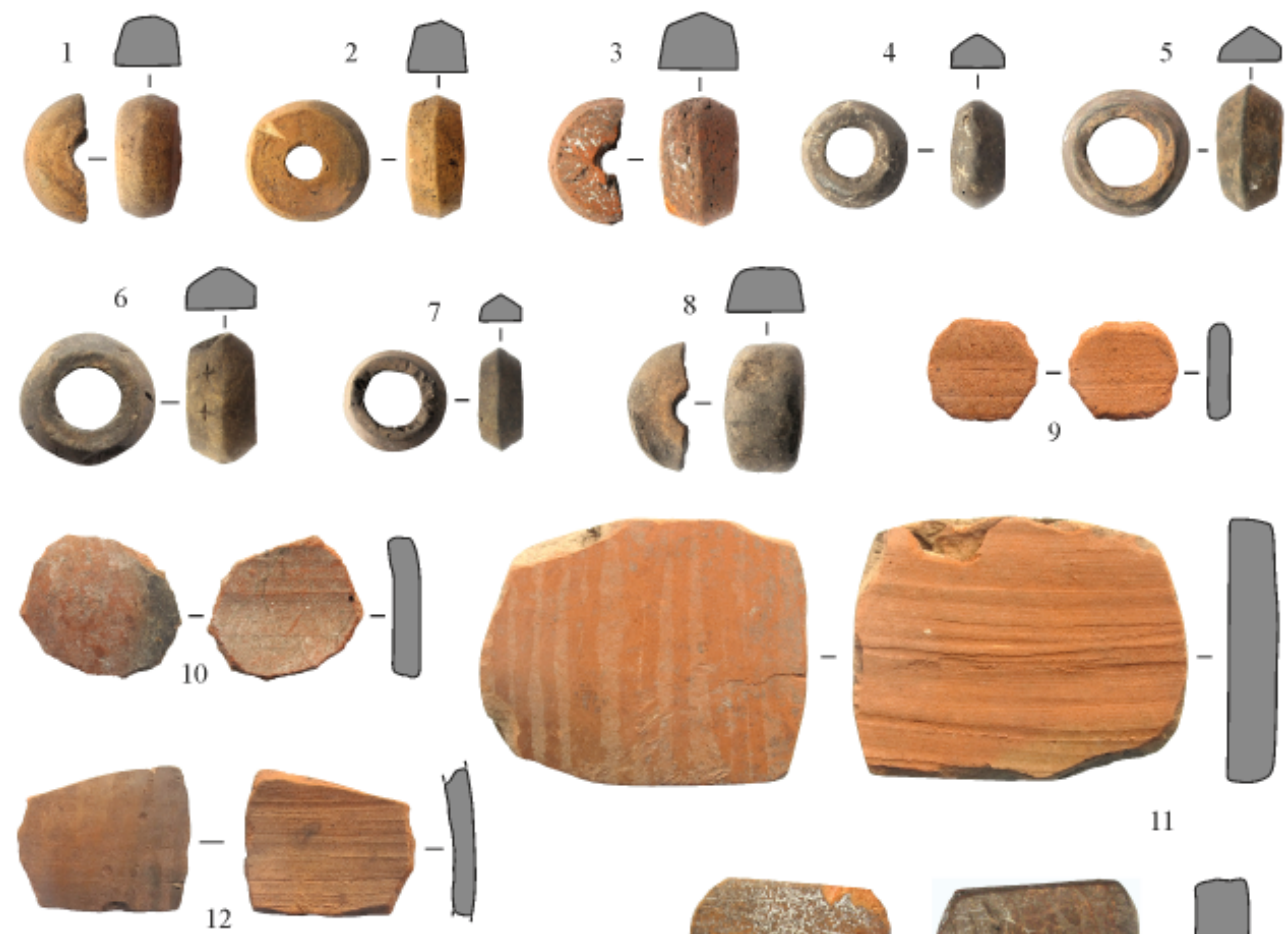

12
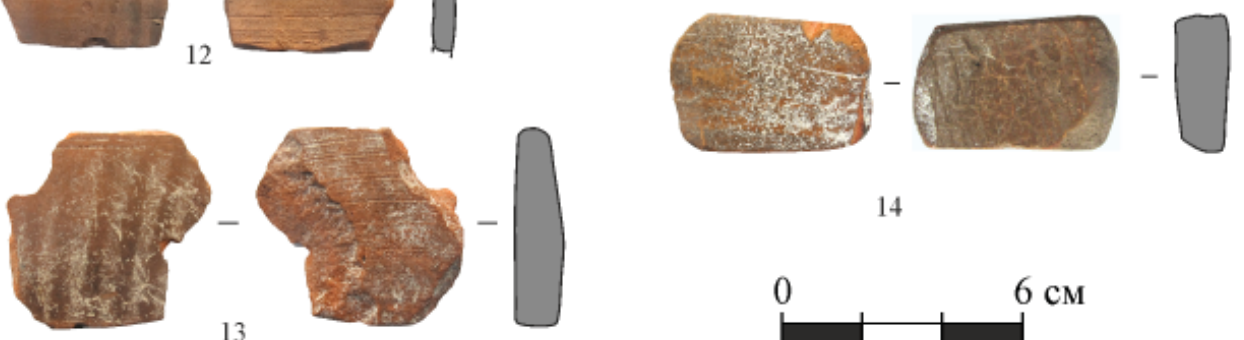

14
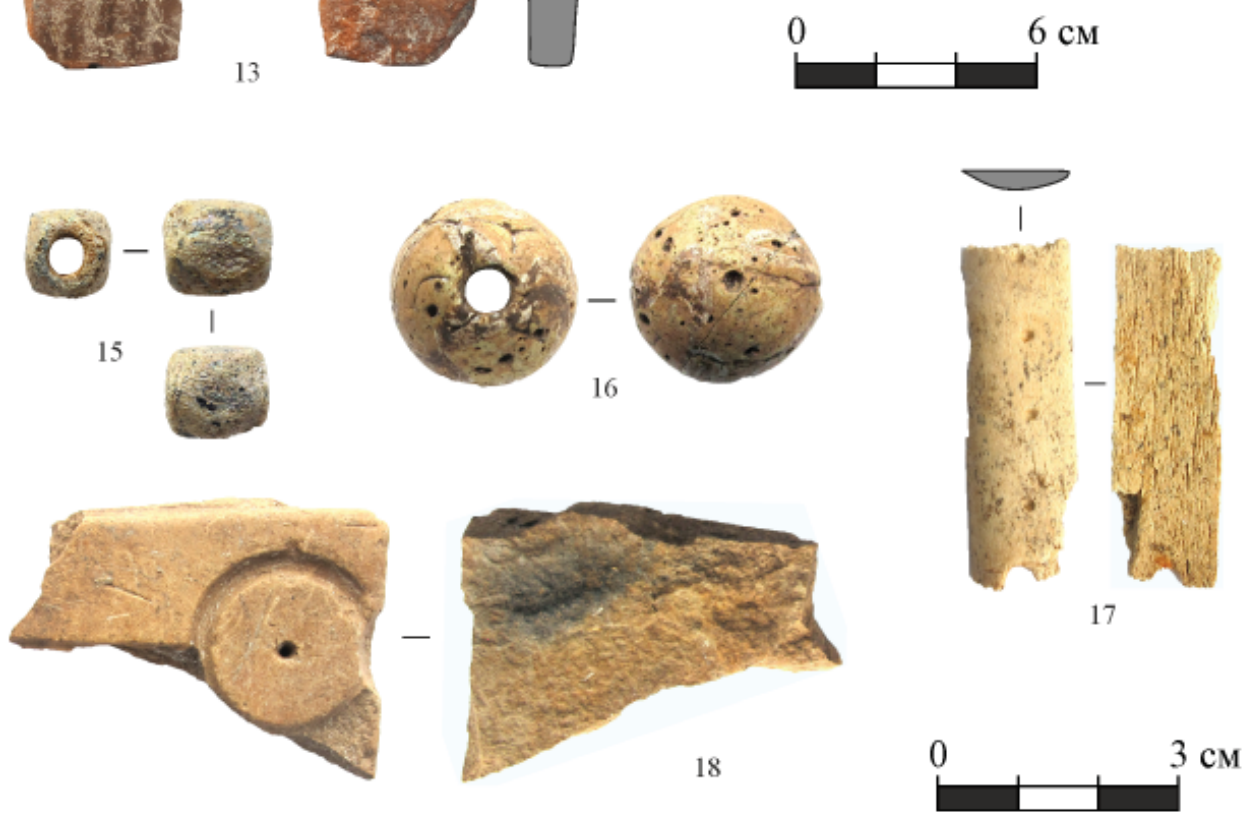

Рис. 7. Балымерское V селище - 2019 г. Вещевой комплекс раскопа III (15-16 - стекло, 17 - кость, 18 - камень, остальное - глина): пряслица (1-8), изделия из стенок сосудов (9-14), бусы (15-16), накладка (17), литейная форма (18)

Fig. 7. Balymery V settlement - 2019. Item complex of excavation III (15-16 - glass, 17 - bone, 18 - stone, others - clay): spindle (1-8), items from vessel walls (9-14), beads (15-16), pad (17), mold (18)

некоторых фрагментах хорошо заметны следы ремонта треснувших сосудов в виде сквозных отверстий. Отверстия в разрезе конусовидной формы диаметром 0,2-0,8 см (рис. 6: 1, 10). Кроме того, встречены единичные фрагменты именьковской керамики (лепной с примесями шамота) с поверхностью, тщательно заглаженной по сырой глине, и желтоватого цвета подлощенные (рис. 6: 9).

Остальная лепная керамика (64 экз. $1,53 \%)$, вследствие малочисленности и фрагментарности не всегда поддается рекон- 
струкции, однако по контексту выявления и особенностям формовки можно отнести в целом ко второй половине I - началу II тыс. н. э. (рис. 6: 14-27). Они отличаются некоторыми различиями в примеси формовочной массы и формах сосудов. В основном их формовочные массы вместе с шамотом содержат примеси песка, выжимки, навоза или органического раствора, в двух фрагментах имеется примесь кальцинированных костей. Поверхности некоторых заглажены (иногда по сырой глине), подлощены или залощены (рис. 6: 14). Орнаментация на сосудах практически отсутствует, обнаружен один прямой венчик с косыми насечками (рис. 6: 15) и второй отогнутый наружу, украшенный по внешнему краю вдавлениями треугольным штампом, образующими зигзаг (рис. 6: 20). Реконструируемые формы принадлежат горшкообразным и мискообразными сосудам. Аналогии некоторым из них можно найти среди древнемордовской керамики (Гришаков, 1990, с. 32-33, табл. I), на памятниках последней четверти I тыс. Ульяновского Поволжья (Вязов, Семыкин, 2016, с. 31, рис. 5: 8) и др. Среди данной керамики выделяется реконструируемый круглодонный сосуд шаровидным туловом в формовочной массе с примесью фракций шамота различных размеров. Шейка невысокая, венчик отогнут наружу с небольшим утолщением по краю в результате формовки (рис. 6: 23). Подбор аналогий может привести к древностям второй половины VI - первой половины VII вв. у с. Кушнаренково в Приуралье (Генинг, 1977, с. 127, рис. 17: 1). С этими же памятниками связан и другой фрагментированный горшковидный сосуд с высоким воронкообразным венчиком и узкой горловиной, резко переходящей к ярко выраженным плечикам (рис. 6: 24). Схожие сосуды происходят с погребений 2 и 21 Кушнаренковского могильника (Генинг, 1977, с. 92, 103, 112, рис. $3: 23 ; 9: 1)$.

В единичном экземпляре найдена стенка неполивного сосуда с рифлением - амфоры трапезундской группы, которая имеет широкие рамки бытования.

К группе керамических находок примыкают пряслица (8 экз.) и изделия из стенок сосудов (5 экз.). Пряслица круговые усеченнобиконические (3 экз.), одно из них с выгнутой поверхностью, и лепные (5 экз.) усеченнобиконические и одно уплощенно-цилиндрическое. Два круговых пряслица диаметром 2,7-3 см при высоте 1,3-1,4 см, одно диаметром 3,2 см при высоте 1,9 см, имеют небольшие диаметры отверстия - 0,7-0,8 см (рис. 7: 1-3). Они красного и желтого цвета и не редки на средневековых памятниках Среднего Поволжья.

Лепные асимметрично усеченно-биконические пряслица имеют диаметр от 2,5 см до 3 см при высоте 1,1-1,4 см. Их диаметр отверстия от 1,1 см до 1,5 см. Они коричневого цвета, поверхность тщательно заглажена (рис. 7: 4-7). На поверхности одного пряслица имеется орнамент в виде одного ряда крестиков (рис. 7: 6), на бортике второго - точечные вдавления, не образующие единый орнаментальный мотив (рис. 7: 7). Данные пряслица типичны для именьковской культуры (Старостин, 1967, с. 21, табл. 21: 4-16). Лепное уплощенно-цилиндрическое пряслице имеет следующие размеры: диаметр 3,2 см, высота 1,8 см, диаметр отверстия 0,7 см (рис. 7: 8). Аналогии ему можно найти как на памятниках второй половины I - первой половины III вв. в Самарском Поволжье (Сташенков, 2005, с. 21 , рис. 6: 4), так и раннеболгарского времени (Казаков, 1992, с. 145, рис. 54: 14).

Керамические изделия из фрагментов стенок общеболгарских сосудов (5 экз.) разнообразны по форме (округлые, овальные, квадратные, прямоугольные, трапециевидные). Края изделий (торцы) заглажены или имеют следы сработанности - потертость, отточенность и сколы. Размеры прямоугольных и трапециевидных форм: длина - 4,3-8,3 см, ширина - 3,4-6,7 cм, толщина стенок - 0,6-1,3 см; квадратного - 4,9×5,2×1 см; овального $-3,6 \times 3,1 \times 0,6$ см. Округлое изделие диаметром составляет 2,4-2,6 см, выточено из стенки толщиной 0,5 см (рис. 7: 9-14). Подобные изделия часто встречаются на булгарских памятниках домонгольского и золотоордынского периода. В настоящее время, по мнению некоторых исследователей, функциональное назначение круглых изделий диаметром 1,9-4 см определяется как предметы для игр (фишки), остальные могли использоваться как ремесленный инструментарий для мздрения шкур и кожи, так и в качестве предмета личной гигиены - скребков для тела (Бадеев, 2019, с. 32-34).

Железные изделия с раскопа представлены ножами и их фрагментами (5 экз.), уздечными накладками (3 экз.), гвоздями (2 экз.), крючком и фрагментом топора. Все ножи универсального функционального назначения, длина лезвий 7,6-8,6 см при общей длине 9,612,4 см. На всех ножах, кроме одного, переход от лезвия к черенку с ярко выраженным 


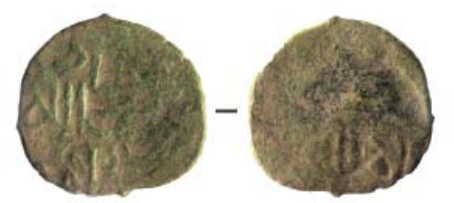

1

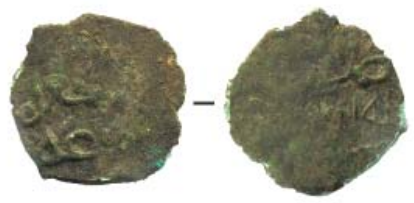

2

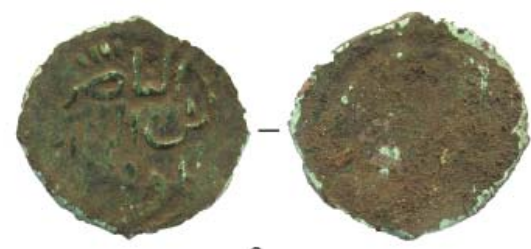

3

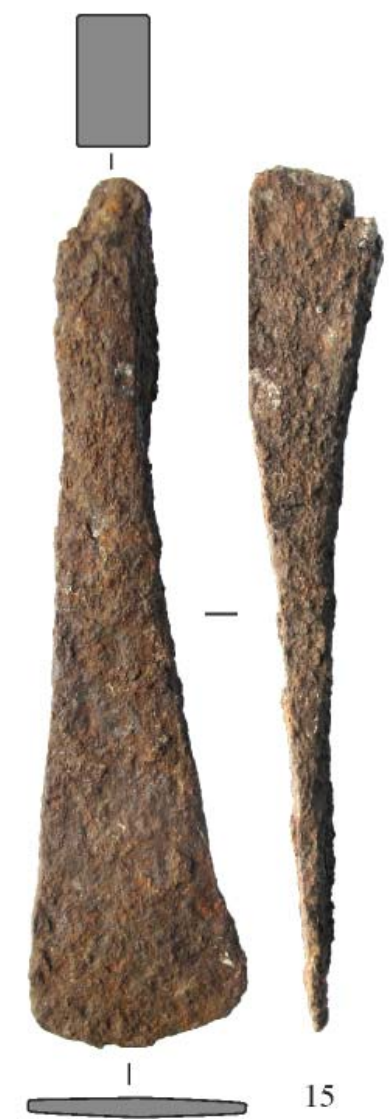

14
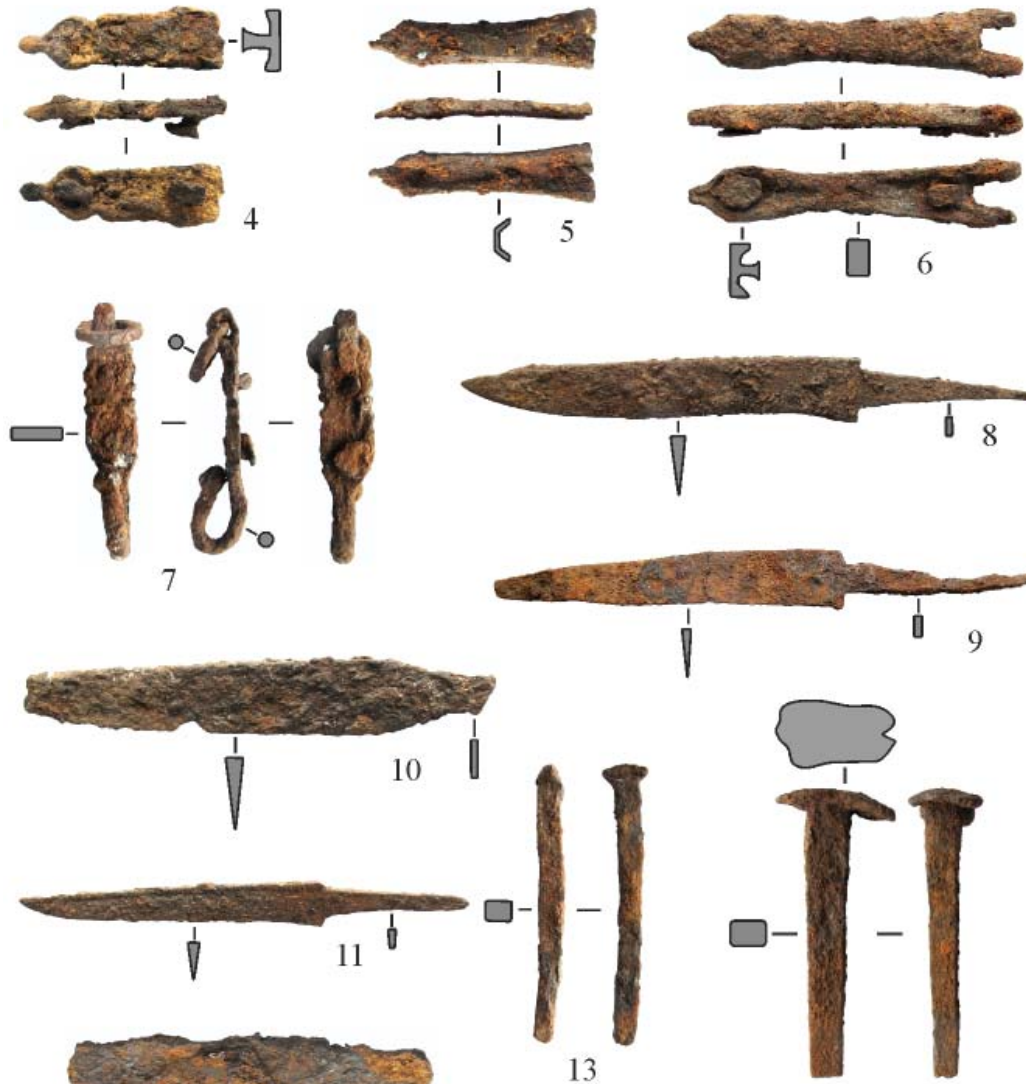

13

7

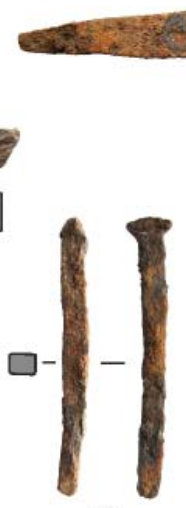

12
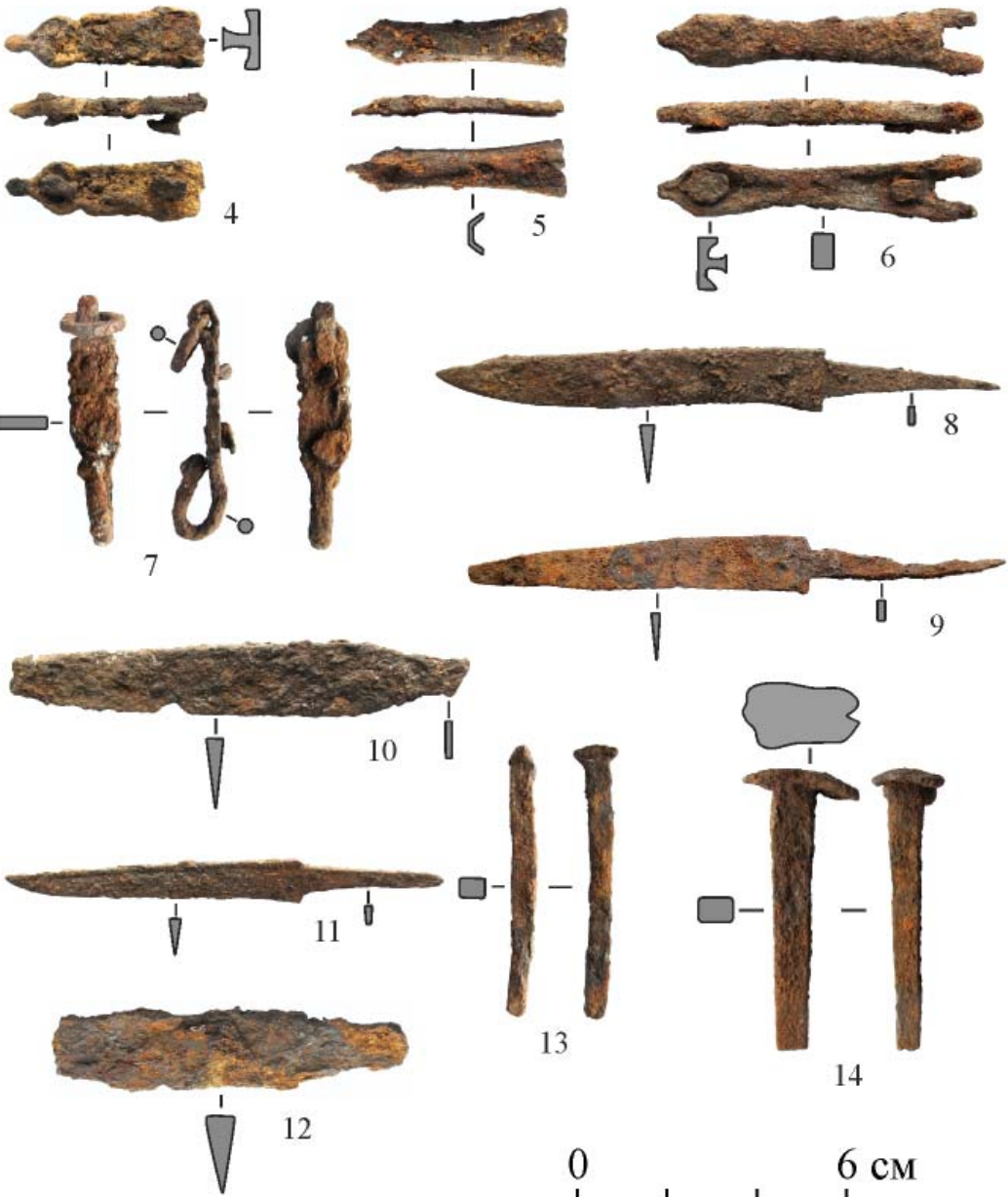

1
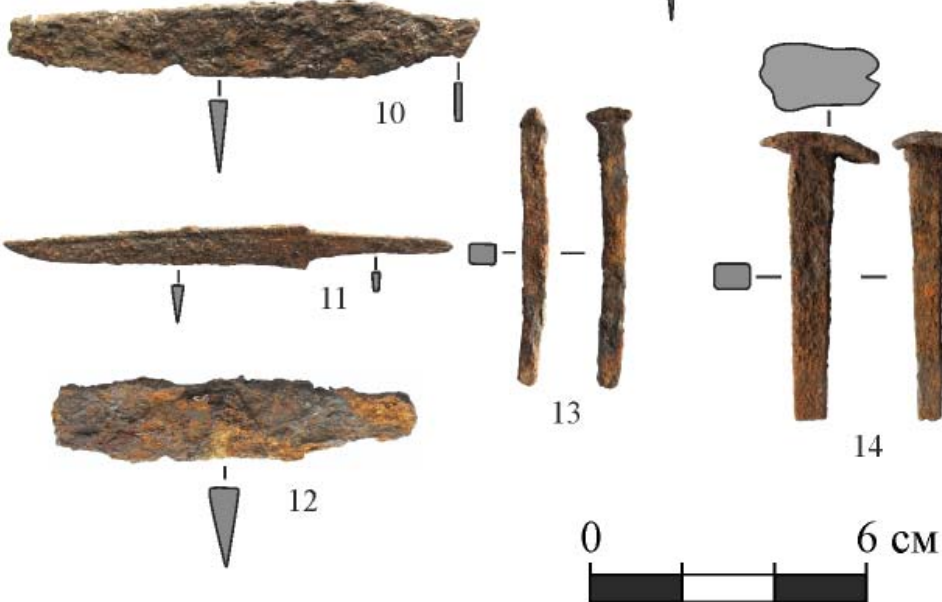

Рис. 8. Балымерское V селище - 2019 г. Вещевой комплекс раскопа III (1-3 - медь, остальное - железо): монеты (1-3), накладки ременные (4-6), крючок колчанный (7), ножи (8-11), гвозди (13-14), топор (15)

Fig. 8. Balymery V settlement - 2019. Item complex of excavation III (1-3 - copper, others - iron): coins (1-3), belt pads (4-6), quiver hook (7), knives (8-11), nails (13-14), axe (15)

упором, налезвияхфиксируетсясработанность (рис. 8: 8-12).

Накладки ременные (уздечные) прямоугольной вытянутой формы с гладким краем нескольких типов. Одна из них объемная сплошная П-образного сечения, имеет переднее килевидное окончание и завершение «ласточкин хвост» (рис. 8: 5). Вторая короткая плоская с небольшим бортиком по краю, имеет переднее шлемовидное окончание и фигурное завершение (рис. 8: 4). Третья накладка составная шарнирная с поперечными перетяжами, имеет килевидное окончание на одном конце и гнезда для штифта на другом (рис. 8: 6). По типологии К.А. Руденко, они близки к типам Б11, Б16б-Б16в и Б5 соответственно (Руденко, 2000а, с. 249-250, рис. 2-3; 2000б, c. 49, рис. 3-4). Подобные накладки, характерные для малиновского этапа (конец XI - XII вв.) аскизской культуры (Кызласов, 1983, рис. 16), нередко происходят с поселений Волжской Булгарии XI-XII вв. (Казаков, 1984, с. 49, рис. 10: 34-36; 1991, с. 140 , рис. 43: 40, 44; 2000, с. 39, рис. 5: 7, 9-12, 22; Руденко, 2015, с. 65 , рис. $6: 6 ; 8: 15)$ и синхронных памятников сопредельных территорий (Иванова, 1982а, с. 
13 , рис. $7: 14 ; 19826$, с. 59 , рис. $6: 6-7 ; 1992,43$, рис. 18: 1-20; Белорыбкин, 2000, с. 130-131, рис. 2: 9-10; 8:2).

Ещё одной находкой, аналогии которой можно найти в малиновском этапе аскизской культуры, является крючок, в исторической литературе более употребляемый с прилагательным «колчанный». Он изготовлен из узкой пластины шириной 1,1 см и толщиной 0,27 см. Один конец пластины сплющен и загнут в ушко, куда вставлено кольцо диаметром 1,5 см, второй заканчивается крючком с шарообразным утолщением. Общая длина изделия (вместе с кольцом) составляет $7 \mathrm{~cm}$. Пластина орнаментирована перетяжками, крючок - насечками. На пластине сохранились две заклепки для крепления на ремне (рис. 8: 7). Аналогичные колчанные крючки происходят с Лаишевского (Чакма) селища и других булгарских памятников (Руденко, с. 42, рис. 28: 26), а также известны в материалах Золоторевского селища (Белорыбкин, 2000 , с. $133-134$, рис. $6: 1-4)$.

Гвозди выкованы из стержня прямоугольного сечения. Они относятся к крепежностроительным и обломаны посередине (рис. 8: 13-14). Топор вытянутый узколезвийный, ширина лезвия 4,8 см (рис. 8: 15). Он обломан у обуха, что затрудняет установление культурно-хронологической принадлежности, тем не менее следует отметить, что подобные формы топоров в Среднем Поволжье скорее характерны для именьковских древностей (Вязов, 2012).

В раскопе обнаружены 3 медные монеты, представляющие собой булгарские фельсы, чеканенные с именем покойного багдадского халифа ан-Насир ли-дин Аллаха (рис. 7: 1-3). Две из них происходят с ямы 7 и описаны выше, третья - из культурного слоя и относится к типу № 7a (вес 2,34 г). Монеты не имеют следов перечеканки штемпелями с именем каана Менгу и датируются 40-ми гг. XIII в. (Сунгатуллина, 2003, с. 15, 71-72). Находки подобных монет на данной территории уже встречались. По сообщению Н.П. Лихачева, в 1889 г. два фельса с именем ан-Насир ли-дин Аллаха (одна с перечеканкой от имени Менгу каана) были обнаружены при костяке, выявленном крестьянином Гребенского выселка на северо-западной окраине с. Балымеры при рытье погреба (Лихачев, 1890, с. 108-110).

Находки предметов из прочих материалов на раскопе единичны. Это фрагменты камен- ной литейной формы и костяной накладки, а также две стеклянные бусины.

Литейная форма представлена обломком створки 4,5×3,3×0,9 см, изготовленной из алевралита. Тыльная сторона отколота, рабочая поверхность тщательно выравнена, на которой частично сохранилось гнездо для отливки ювелирного изделия с элементом в виде кольца диаметром 2 см (рис. 7: 18).

Накладка в сечении полукруглой формы шириной 1,3 см, высотой 0,3 см, сохранилась в длину 4,1 см. Концы обломаны, на одном заметны следы сквозного отверстия. На лицевую поверхность по центру длинной оси нанесены круглые вдавления диаметром около 0,1 см, на расстоянии 0,9-1,1 см друг от друга (рис. 7: 17). Возможно, накладка является скрепляющей планкой двухстороннего наборного гребня, которые известны с Болгарского городища (Закирова, 1988, с. 230, рис. 102: 3) и по материалам Новгорода датируются XII-XIII вв. (Колчин, 1958, с. 102, рис. 5: 7; 6), или костяной накладкой на колчан, схожие с которой находятся среди материалов Билярского городища (Культура Биляра, 1985, с. 137, табл. XLVII: 6).

Бусы имеют характерные следы иризации, вследствие чего обесцвечены (рис. 7: 15-16). Одна из них шарообразная диаметром 2,1 cм, вторая - граненая, представляет собой прямоугольный параллелепипед со срезанными углами размером $1,2 \times 1 \times 1,1 \mathrm{~cm}$.

Исходя из результатов исследований, территория Балымерского V селища начала осваиваться в именьковское время (IV-VII вв.). В период Волжской Булгарии территория именьковского селища перерабатывается в результате хозяйственной деятельности и распашки, о чём свидетельствует большое количество именьковского материала в слоях булгарского поселения. Время бытования булгарскогопоселения в результате исследований определено интервалом XI (скорее всего, его второй половины) - середины XIII вв., синхронно функционированию Балымерского II могильника. После монгольского завоевания поселение продолжало существовать на этапе становления Улуса Джучи, о чём могут свидетельствовать находки монет 40-х гг. XIII в., обнаруженных как в культурном слое, так и в одном из объектов. Вероятно, с данным периодом жизни поселения связаны погребения на курганном могильнике, расположенном к северо-западу от селища. 


\section{ЛИТЕРАТУРА}

Археологическая карта Татарской АССР. Западное Закамье. Ч. І / Отв. ред. П.Н. Старостин. Казань: ИЯЛИ КФАН СССР, 1986. 112 с.

Бадеев Д.Ю. О вариативности использования изделий из фрагментов керамических сосудов (по материалам исследований средневекового Болгара) // Азак и мир вокруг него. Материалы Международной научной конференции. Азов, 14-18 октября 2019 г. / Донские древности. Вып. 12 / Отв. ред. Е.Е. Мамичев. Азов: Изд-во Азовского музея-заповедника, 2019. С. 30-34.

Вязов Л.А. О происхождении топоров именьковской культуры // Актуальные вопросы археологии Поволжья. К 65-летию студенческого научного археологического кружка Казанского университета / Отв. ред. С.И. Валиулина. Казань: ЯЗ, 2012. С. 43-53.

Вязов Л.А., Семыкин Ю.А. Городище и селище Новая Беденьга: эпоха Великого переселения народов в Ульяновском Предволжье / Археология Симбирского-Ульяновского Поволжья. Вып. 1. Ульяновск: НИИ истории и культуры им. Н.М. Карамзина, 2016. 227 с.

Генинг В.Ф. Памятники у с. Кушнаренково на р. Белой (VI - VII вв. н.э.) // Исследования по археологии Южного Урала / Отв. ред. Р.Г. Кузеев. Уфа: БФАН СССР, 1977. С. 90-136.

Гришаков В.B. Керамика среднецнинской мордвы // Средневековые памятники Окско-Сурского междуречья / Труды МНИИЯЛИЭ. Вып. 99 / Отв. ред. М.Ф. Жиганов. Саранск: Мордов. кн. изд-во, 1990. C. 32-52.

Ефимова А.М. Городецкое селище и болгарское городище у с. Балымеры Татарской АССР // МИА. № 111. М.: Наука, 1962. С. 25-48.

Жиромский Б.Б. Древнеродовое святилище «Шолом» // МИА. № 61. М.: Изд-во АН СССР, 1958. C. 424-450.

Закирова И.А. Косторезное дело Болгара // Город Болгар: Очерки ремесленной деятельности / Отв. ред. Г.А. Федоров-Давыдов. М.: Наука, 1988. С. 220-243.

Казаков Е.П. Булгарское село Х-ХІІІ веков низовий Камы. Казань: Татар. кн. изд-во, 1991. 176 с.

Казаков Е.П. Культура ранней Волжской Болгарии. М.: Наука, 1992. 335 с.

Кокорина Н.A. Керамика Волжской Булгарии второй половины XI - начала XV веков (к проблеме преемственности булгарской и булгаро-татарской культур). Казань: ИИ АН РТ, ИА РАН, 2002. 383 с.

Кочкина А.Ф. Находки предметов «аскизского» круга с Муромского городка // Археология Поволжья / Отв. ред. Г.Н. Белорыбкин. Пенза: Пензенский государственный педагогический университет им. В.Г. Белинского, 2001. С. 140-142.

Колчин Б.А. Хронология новгородских древностей // СА. 1958. № 2. С. 92-111.

Культура Биляра. Булгарские орудия труда и оружие X-XIII вв. / Отв. ред. А.Х. Халиков. М.: Наука, 1985. $216 \mathrm{c}$.

Кызласов И.Л. Аскизская культура Южной Сибири X-XIV вв. // САИ. Вып. Е3-18. М.: Наука, 1983. $128 \mathrm{c}$.

Лихачев H. О двух фельсах, найденных около сельца Балымер, Казанской губернии // Записки Восточного Отделения Императорского Русского Археологического Общества. Т. V. 1890. СПб.: Типография Императорской Академии Наук, 1890-1891. С. 108-110.

Руденко К.А. Булгарские железные пряжки и накладки (X - XIV вв.) // Научное наследие А.П. Смирнова и современные проблемы археологии Волго-Камья / Труды ГИМ. Вып. 122 / Отв. ред. И.В. Белоцерковская. М.: ГИМ, 2000. С. 237-253.

Руденко К.A. Датировка находок «аскизского круга» из Волжской Булгарии // Аскизские древности в средневековой истории Евразии / Отв. ред. К.А. Руденко. Казань: ГОМ РТ, 2000. С. 47-127.

Руденко K.A. Тюркский мир и Волго-Камье в XI-XIV вв.: Изделия аскизского круга в Среднем Поволжье. Казань: Заман, 2001. 256 с.

Руденко К.А. Исследования археологических памятников у с. Балымери в 1996-1998 гг. // Вопросы древней истории Волго-Камья / Отв. ред. Е.П. Казаков. Казань: Мастер Лайн, 2002. С. 70-77.

Руденко K.A. Булгарские святилища эпохи средневековья XI-XIV вв. (по археологическим материалам) // Культовые памятники Камско-Вятского региона / Отв. ред. Н.И. Шутова. Ижевск: УИИЯЛ УрО PAH, 2004. C. 36-66.

Руденко К.А. Исследования VI Алексеевского и Мурзихинского селищ в Татарстане в 1992-1996 г. Казань: Издательский дом «Казанская недвижимость», 2015. 400 с.

Свод археологических памятников Республики Татарстан. Т. 3. / Отв. ред. А.Г. Ситдиков, Ф.Ш. Хузин. Казань, 2007. 528 с. 
Смолин В.Ф. Раскопки «Шолома» в селе Балымерах Спасского кантона Татреспублики в 1924-1925 гг. (краткий обзор) // ИОАИЭ. Т.33. Вып. 2-3. Казань, 1926. С. 113-130.

Спицын А.А. Заметки из поездки 1898 года // Известия ИАК. Вып. 60. Спб., 1916. С. 73-93.

Старостин П.Н. Балымерский «Шелом»- городище // Вопросы истории и литературы Среднего Поволжья / Ред. А.М. Залялов. Казань: ИЯЛИ, 1965. С. 59-68.

Старостин П.Н. Памятники именьковской культуры / САИ. Вып. Д1-32. М.: Наука, 1967. 97 с.

Сингатуллина А.З. Джучидские монеты поволжских городов ХІІІ в. Казань: Заман, 2003. 192 с.

Халикова Е.А. Археологические исследования в Куйбышевском районе ТАССР // КСИА. Вып. 104. М.: Наука, 1965. С. 110-116.

Хлебникова T.A. Керамика памятников Волжской Болгарии. К вопросу об этнокультурном составе населения. М.: Наука, 1984. 241 с.

Хлебникова T.A. Неполивная керамика Болгара // Город Болгар: Очерки ремесленной деятельности / Отв. ред. Г.А. Федоров-Давыдов. М.: Наука. 1988. С. 7-102.

Чижевский А.А., Хисяметдинова АА., Вязов Л.А., Салова Ю.А. Исследования вала городища «Шолом» в 2014 г. // Поволжская археология. 2017. №2 (20). С. 108-126.

Шиилевский С.М. Древние города и другие булгарско-татарские памятники в Казанской губернии. Казань: Типография Казанского ун-та, 1877. 586 с.

\section{Информация об авторах:}

Валиев Ренат Рафаилович, кандидат исторических наук, старший научный сотрудник, Институт археологии им. А.Х. Халикова АН РТ (г. Казань, Россия); vrr80@yandex.ru.

Степанов Родион Алексеевич, аспирант отдела средневековой археологии, Институт археологии им. А.Х. Халикова АН РТ (г. Казань, Россия); outdanger@bk.ru

\section{REFERENCES}

Starostin, P. N. (ed.). 1986. Arkheologicheskaia karta Tatarskoi ASSR. Zapadnoe Zakam'e (Archaeological Map of the Tatar ASSR. Western Trans-Kama Region) I. Kazan: Institute of Language, Literature and History, Kazan Branch of the USSR Academy of Sciences (in Russian).

Badeev, D. Yu. 2019. In Mamichev, E. E. (ed.). Azak i mir vokrug nego (Azak and the World Around It). Series: Donskie drevnosti (Antiquities of the Don) 12. Azov: Azov Historical-Archaeological and Palaeontological Museum-Reserve Publ., 30-34 (in Russian).

Vyazov, L. A. 2012. In Valiulina, S. I. (ed.). Aktual'nye voprosy arkheologii Povolzh'ia. K 65-letiiu studencheskogo arkheologicheskogo kruzhka Kazanskogo universiteta (Current Issues of the Volga Region Archaeology: 65 th Anniversary of the Students' Archaeological Group in the Kazan University). Kazan: "IaZ" Publ, 43-53 (in Russian).

Vyazov, L.A., Semykin, Yu.A. 2016. Gorodishhe i selishhe Novaja Beden'ga: epoha Velikogo pereselenija narodov v Ul'janovskom Predvolzh'e (Novaya Bedenga hillfort and settlement: the Migration period in the Ulyanovsk region). Series: Arheologiia Simbirskogo-Ul'ianovskogo Povolzh'ia (Archaeology of the SimbirskUlyanovsk Volga Region) 1. Ulyanovsk, (in Russian).

Gening, V. F. 1977. In Kuzeev, R. G. (ed.). Issledovaniia po arkheologii Iuzhnogo Urala (Studies on the Archaeology of the Southern Urals). Ufa: Bashkir Research Center, Ural Branch of the Russian Academy of Sciences, 90-136 (in Russian).

Grishakov, V. V. 1990. In Zhiganov, M. F. (ed.). Srednevekovye pamiatniki Oksko-Surskogo mezhdurech'ia (Medieval Sites of the Oka-Sura Interfluve). Series: Proceedings of the Mordovian Research Institute of Language, Literature, History and Ethnography 99. Saransk: "Mordovskoe knizhnoe izdatel'stvo" Publ., 32-52 (in Russian).

Efimova A. M. 1962. In Materialy i issledovaniia po arkheologii (Materials and Studies in the Archaeology) 111. Moscow: "Nauka" Publ., 25-48 (in Russian).

Zhiromsky B. B. 1958. In Materialy $i$ issledovaniia po arkheologii (Materials and Studies in the Archaeology) 61, 424-450 (in Russian).

Zakirova, I. A. 1988. In Fedorov-Davydov, G. A. (ed.). Gorod Bolgar. Ocherki remeslennoi deiatel'nosti (Town of Bolgar. Essays on Handicrafts). Moscow: "Nauka" Publ., 220-243 (in Russian).

Kazakov, E. P. 1991. Bulgarskoe selo X-XIII vekov nizovii Kamy $\left(10^{\text {th }}-13^{\text {th }}\right.$ Century Bulgar Village in the Lower Kama Region). Kazan: "Tatarskoe knizhnoe izdatel'stvo" Publ. (in Russian).

Kazakov, E. P. 1992. Kul 'tura rannei Volzhskoi Bolgarii (etapy etnokul'turnoi istorii) (Culture of the Early Volga Bulgaria: Stages of the Ethnic-Cultural History). Moscow: "Nauka" Publ. (in Russian). 
Kokorina, N. A. 2002. Keramika Volzhskoi Bulgarii vtoroi poloviny XI - nachala XV vv.: K probleme preemstvennosti bulgarskoi i bulgaro-tatarskoi kul'tur (Ceramic Ware in Volga Bulgaria during the Second Half of the 11th - Beginning of the 15th Centuries (on the Issue on Succession of the Bulgar and Bulgar-Tatar Cultures)). Kazan: Institute of History named after Shigabuddin Mardjani, Tatarstan Academy of Sciences; Russian Academy of Sciences, Institute of Archaeology (in Russian).

Kochkina, A. F. 2001. In Belorybkin, G. N. (ed.). Arkheologiia Povolzhia (Archaeology of the Volga Area). Penza: Penza State Pedagogical University, 140-142 (in Russian).

Kolchin, B. A. 1958. In Sovetskaia Arkheologiia (Soviet Archaeology) (2), 92-111 (in Russian).

Khalikov, A. Kh. (ed.). 1985. Kul'tura Biliara. Bulgarskie orudiia truda i oruzhie X-XIII vv. (Bilyar Culture. Bulgar Tools and Weapons in 10 $10^{\text {th }}-13^{\text {th }}$ Centuries). Moscow: "Nauka" Publ. (in Russian).

Kyzlasov, I. L. 1983. Askizskaya kul'tura Yuzhnoy Sibiri X-XIV vv. (Askiz Culture of South Siberia in the 10 $0^{\text {th }}-14^{\text {th }} c c$.). Series: Svod Arkheologicheskikh Istochnikov (Corpus of Archaeological Sources) E3-18. Moscow: "Nauka" Publ. (in Russian).

Likhachev, A. F. 1890-1891. In Zapiski Vostochnogo otdeleniia Imperatorskogo Russkogo arkheologicheskogo obshchestva (Proceedings of the Oriental Branch of the Imperial Russian Geographic Society). V. Saint-Petersburg: Imperial Academy of Sciences Publ., 108-110 (in Russian).

Rudenko, K. A. 2000. In Belotserkovskaia, I. V. (ed.). Arkheologicheskii sbornik. Pogrebal'nyi obriad (Archaeological Collection of Papers. Funeral Rite). Series: Proceedings of the State Historical Museum 122. Moscow: State Historical Museum, 237-253 (in Russian).

Rudenko, K. A. 2000. In Rudenko, K. A. (ed.). Askizskie drevnosti v srednevekovoi istorii Evrazii (Askiz Antiquities in the Medieval History of Eurasia). Kazan: State United Museum of the Republic of Tatarstan, 47-127 (in Russian).

Rudenko, K. A. 2001. Tiurkskii mir i Volgo-Kambe v XI-XIV vv.: Izdeliia askizskogo kruga v Srednem Povolzhbe (Turkic World and the Volga-Kama Region in the $11^{\text {th }}-14^{\text {th }}$ Cc.: Articles of the Askiz Range in the Middle Volga Kegion). Kazans: "Zaman” Publ. 141 (in Russian).

Rudenko, K. A.. 2002. In Kazakov, E. P. (ed.). Voprosy drevnei istorii Volgo-Kam'ia (Issues of Ancient History of the Volga-Kama Region). Kazan: "Master-Line" Publ., 70-77 (in Russian).

Rudenko, K. A. 2004. In Shutova, N. I. (ed.). Kul'tovye pamiatniki Kamsko-Viatskogo regiona: Materialy $i$ issledovaniia (Cult Sites of Kama and Vyatka Rivers Region: Materials and Studies). Izhevsk: Udmurtian Institute of History, Language, and Literature, Ural Branch of the Russian Academy of Sciences, 36-66 (in Russian).

Rudenko, K. A. 2015. Issledovaniia VI Alekseevskogo i Murzikhinskogo selishch v Tatarstane v 1992-1996 g. (Studies of VI Alekseevskoye and Murzikha Settlements in Tatarstan in 1992-1996). Kazan: "Kazanskaia nedvizhimost"' Publ. (in Russian).

Sitdikov, A. G., Khuzin, F. Sh. (ed.). 2007. Svod arkheologicheskikh pamiatnikov Respubliki Tatarstan (Corpus of Archaeological Sites of the Republic of Tatarstan). Kazan (in Russian).

Smolin, V. F. 1926. In Izvestiia obshchestva arkheologii, istorii i etnografii pri Kazanskom imperatorskom universitete (Reports of the Society of Archaeology, History and Ethnography Affiliated with Kazan Imperial University) 33 (2-3). Kazan, 113-130 (in Russian).

Spitsyn, A. A. 1916. In Izvestiia Imperatorskoi arkheologicheskoi komissii (Proceedings of the Imperial Archaeological Commission) 60. Saint Petersburg, 73-93 (in Russian).

Starostin, P. N. 1965. In Zalyalov, A. M. (ed.). Voprosy istorii i literatury Srednego Povolzh'ia (Issues of History and Literature of the Middle Volga Region). Kazan: Institute of Language, Literature and History, Kazan Branch of the USSR Academy of Sciences, 59-68 (in Russian).

Starostin, P. N. 1967. Pamiatniki imen'kovskoi kul'tury (Sites of the Imenkovo Culture). Series: Svod Arkheologicheskikh Istochnikov (Corpus of Archaeological Sources) D1-32. Moscow: "Nauka" Publ. (in Russian).

Singatullina, A. Z. 2003. Dzhuchidskie monety povolzhskikh gorodov XIII v. (Jochid Coins in Volga Towns in $13^{\text {th }}$ c.). Kazan: "Zaman" Publ. (in Russian).

Khalikova, E. A. 1965. In Kratkie soobshcheniia Instituta arkheologii (Brief Communications of the Institute of Archaeology) 104. Moscow: "Nauka" Publ., 110-116 (in Russian).

Khlebnikova, T. A. 1984. Keramika pamiatnikov Volzhskoi Bolgarii: (K voprosu ob etnokul'turnom sostave naseleniia) (Ceramic Ware ft he Volga Bolgaria Sites. On the Issue of Ethnic and Cultural Composition of the Population). Moscow: "Nauka" Publ. (in Russian).

Khlebnikova, T. A. 1988. In Fedorov-Davydov, G. A. (ed.). Gorod Bolgar. Ocherki remeslennoi deiatel'nosti (Town of Bolgar. Essays on Handicrafts). Moscow: "Nauka" Publ., 7-102. (in Russian). 
Chizhevsky, A. A., Khisyametdinova, A. A., Vyazov, L. A., Salova, Yu. A. 2017 In Povolzhskaya arkheologiya (Volga River Region Archaeology) 20 (2), 108-126 (in Russian).

Shpilevskii, S. M. 1877. Drevnie goroda i drugie bolgarsko-tatarskie pamiatniki v Kazanskoi gubernii (Ancient Towns and Other Bulgar-Tatar Sites in the Kazan Province). Kazan: Typography of the Kazan University (in Russian).

\section{About the Authors:}

Valiev Renat R. Candidate of Historical Sciences, Institute of Archaeology named after A. Kh. Khalikov, Academy of Sciences of the Republic of Tatarstan. Butlerov Str., 30, Kazan, 420012, the Republic of Tatarstan, Russian Federation; vrr80@yandex.ru

Stepanov Rodion A. Institute of Archaeology named after A.Kh. Khalikov, Academy of Sciences of the Republic of Tatarstan. Butlerov St., 30, Kazan, 420012, the Republic of Tatarstan, Russian Federation; outdanger@bk.ru

Статья поступила в журнал 01.04.2021 г.

Статья принята к публикации 01.04.2021 г.

Авторы внесли равноценный вклад в работу. 